\title{
Camp David Sonrası ABD-Misır Yakınlaşması: Askeri Boyut
}

\author{
Alptuğ Kuduoğlu*
}

\section{Öz}

Camp David süreciyle birlikte ABD ile Mısır arasında bir yakınlaşma başlamıştır. $\mathrm{Bu}$ yakınlaşmanın kritik boyutlarından birisi askeri boyuttur. Askeri alanda Mısır ordusu ABD'yle silah antlaşmaları, ortak tatbikatlar, maddi yardımlar, ortak operasyonlar, istihbarat çalışmaları gibi birçok farklı konuda iş birliği gerçekleştirmiştir. Böylece $\mathrm{ABD}$ bölgesel politikalarında iş birliği içerisinde çalışabileceği bir ordu kazanmayı hedeflemiştir. Bu çalışma içerisinde Camp David Süreci sonrası dönemde Mısır ile $\mathrm{ABD}$ arasındaki ilişkinin askeri boyutu incelenmiştir. $\mathrm{ABD}$ ve Mısır tarafından imzalanan silah antlaşmalarının içeriklerine ve maliyetlerine dair bilgilere yer verilmiştir. ABD'nin Mısır'a askeri alanda gerçekleştirdiği mali yardımlardan söz edilmiştir. ABD-Mısır arasındaki ortak çalışmalar ve operasyonlar üzerinde durulmuştur. Böylece, ABD-Mısır arasındaki yakınlaşmanın askeri yönünü yansıtmak amaçlanmıştır. 2011-2013 yıllarında yaşanan siyasi olayları daha iyi kavramak adına iki ülke arasındaki bu yakınlaşmayı anlamak faydalı olacaktır.

Anahtar Kelimeler: ABD, Mısır, Ordu, Silah Antlaşmaları, Camp David Süreci

Doktora Öğrencisi, Marmara Üniversitesi, Ortadoğu ve İslam Ülkeleri Araştırmaları Enstitüsü, alptug.kuduoglu@gmail.com 


\title{
U.S-Egypt Rapprochement After Camp David: Military Dimension
}

\author{
Alptuğ Kuduoğlu*
}

\begin{abstract}
A rapprochement between U.S and Egypt has started with the Process of Camp David. One of the critical aspects of this rapprochement is military dimension. In military area, Egyptian Army has realized cooperation with United States on many different topics such as arms sales, joint exercises, financial aids, joint operations, investigation practices. So, U.S has aimed to provide an army that work with itself in cooperation for its regional policies. In this work, military dimension of relationship between United States and Egypt after the term of Camp David Process has been examined. It has been given placed to data on contents and costs of arms agreements that has been signed by United States and Egypt. The economic aids in military area that the United States has performed to Egypt has been mentioned. It has been emphasized the works and operations between U.S-Egypt. Thus, it has been intended to reflect the military aspect of rapprochement between U.S-Egypt. To understand better the happening political events in years of 2011-2013, it would be utilized to understand of this rapprochement between two countries.
\end{abstract}

Keywords: United States, Egypt, Army, Arms Sale Agreements, Camp David Process

$\mathrm{PhD}$ Student, Marmara University, Institute Research of Middle East and Islamic Countries, alptug.kuduoglu@gmail.com 


\section{Giriş}

Ortadoğu'da devlet yapılarını anlayabilmek ve devletlerarası ilişkileri kavrayabilmek için dikkatle incelenmesi gereken konulardan birisi askerigüvenlik konusudur. Ortadoğu devletlerinin birçoğunda ordu rejim yapısı içerisinde merkezi bir konuma sahiptir. Bu nedenle askeri alanda yaşanan gelişmeler siyasi alanı da doğrudan etkilemektedir. Özellikle Batılı devletler silah antlaşmaları, askeri yardımlar, ortak askeri çalışmalar, eğitim çalışmaları gibi birtakım adımlar atarak Ortadoğu ülkeleri ile askeri alanda ilişkiler geliştirmektedirler. Askeri alanda kurdukları yakınlık siyasette de bir yakınlık kurulmasına vesile olmaktadır. ABD bu alanda öne çıkan ülkelerden birisidir.

Ordunun rejim yapısı içerisinde merkezde olduğu Ortadoğu ülkelerinden birisi Mısır'dır. 1952 Devrimi sonrası Mısır Nasır liderliğinde ordu merkezli bir rejim inşa etmiştir. Askerler birçok alanda etkin olmuşlardır. M1sır bu dönemde dış politikada Batı karşıtı bir çizgi takip etmiştir. Askeri alandaki ihtiyaçları karşılamak adına da bu çerçevede hareket edilmiştir. Misır'ın lideri Nasır 1970 yılında hayatını kaybettikten sonra ise Enver Sedat onun yerini almıştır. Sedat döneminin Mısır tarihi açısından kritik bir dönem olduğu ifade edilebilir. Bu dönemde özellikle dış politikada önemli bir dönüşüm yaşanmıştır. Nasır'ın izlediği çizgi terk edilmiş, ABD ile M1sır adım adım birbirine yaklaşmıştır. 1970'lerin sonlarında Camp David Süreci ile birlikte başlayan iki ülke arasındaki yakınlaşma her geçen yıl daha da kuvvetlenmiş, Mısır ABD'nin Ortadoğu'daki en önemli müttefiklerinden birisi haline gelmiştir. Bugün iki devlet arasında birçok farklı alanda iş birliği söz konusudur. Askeri alan bu alanlar içerisinde belki de en önemlisidir. ABD Misır siyasetinde kritik bir konumda olan ordu ile ilişkilerini kuvvetlendirerek Ortadoğu'daki bölgesel politikalarını başarıya ulaştırmaya çalışmaktadır. Bir başka ifadeyle; ABD Mısır ordusunu desteklemekte, Mısır ordusu da ABD'nin bölgesel politikalarında ihtiyaç duyduğu anda kendisine gerekli yardımı yapmaktadır. Bu bazen doğrudan ABD operasyonlarına dâhil olmak şeklinde, bazen ise lojistik destek vermek ya da askeri tesisleri kullanıma açmak gibi yöntemler vasıtasıyla yapılmaktadır. Kısacası karşılıklı bir iş birliği ve uyum söz konusudur. $\mathrm{Bu}$ iş birliği ve uyumun merkezinde de ABD'nin Mısır'a yapmış olduğu askeri yardımlar bulunmaktadır. 
ABD'nin Mısır ordusu ile kurduğu sıkı bağlar 2010 yılındaki Arap Devrimleri sürecinde de gündeme getirilmiştir. Mübarek'in devrilmesi sürecinde ordunun pozisyonunun belirlenmesinde ABD'nin rolünün olup olmadığı, Mursi'ye yönelik gerçekleştirilen 2013 yılındaki Sisi Darbesi'nde ABD-Mısır ordusu bağlantısının etkili olup olmadığ kamuoyunda tartışılmıştır. Bütün bu tartışmaları daha iyi anlayabilmek adına Mısır ordusu ile ABD arasındaki ilişkiyi irdelemek oldukça önemlidir. Bu çalışmada Camp David sonrası başlayan ABD-Mısır yakınlaşması kapsamında askeri alandaki ilişkiler ele alınmaktadır. Silah antlaşmaları, askeri yardımlar, ortak çalışmalar gibi iki ülke arasında askeri alanda yapılan girişimlerden söz edilmektedir. Öncelikle Enver Sedat ve Hüsnü Mübarek dönemlerine değinilmektedir. $\mathrm{Bu}$ dönemlerde gerçekleştirilen iş birlikleri üzerinde durmak ve bu sayede 2010 yılı sonrası süreçte yaşanan gelişmelere 1şı tutmak amaçlanmaktadır. Mısır ordusu bu dönemlerde ABD’ye Ortadoğu'daki operasyonlarında katkıda bulunmuştur. Daha sonraki bölümde 2011-2013 yılları arasındaki Silahlı Kuvvetler Yüksek Konseyi'nin geçici iktidarı ve seçim sonrası Mursi iktidarı dönemine geçilmektedir. Çalışmanın sonunda ise Sisi dönemi üzerinde durulmaktadır.

\section{Sedat Dönemi: Camp David'e Giden Yol}

1970 yılında Mısır devletinin başına geçen Sedat en başta iç siyasetteki yerini sağlamlaştırmak adına çalışmalar yapmıştır. 1971 yılında muhaliflerini tasfiye ettikten sonra diş politikaya yönelmiştir. İsrail ile devam eden savaşın Mısır ekonomisi üzerindeki olumsuz etkisini bilen Sedat, ABD ile yakınlaşarak diplomatik bir çözüm bulmayı hedeflemiştir. SSCB'den uzaklaşma amacıyla 1972 yılında Mısır'daki yaklaşık 20.000 Sovyet danışmanı ülkeden gönderme kararı almıştır. ${ }^{1}$ Ancak Sedat'ın bu hamlesi ABD tarafında karşıllık bulmamıştır. Bunun üzerine Sedat "sınırlı bir savaş" şeklinde adlandırılabilecek bir plana yönelmiştir. İsrail ile savaşarak ABD'yi meseleye dâhil etmeyi ve soruna kalıcı bir çözüm bulmayı amaçlamıştır. ${ }^{2}$

1 William L. Cleveland, Modern Ortadoğu Tarihi, (İstanbul: Agora Kitaplığı, 2008), 416-417.

2 A. Lutfi al-Sayyid Marsot, Mısır Tarihi: Arapların Fethinden Bugüne, (İstanbul: Tarih Vakfi Yurt Yayınları, 2010), 131-132. 
Mısır ve Suriye aralarında anlaşarak 1973 yılında İsrail'e saldırıyı başlatmışlardır. Yahudilerin kutsal günü Yom Kippur'a rastlayan günde başlatılan saldırı ilk aşamada çok etkili olmuştur. Mısır ve Suriye orduları savaşta önemli başarılar kazanmış, İsrail ordusu büyük kayıplar vermiştir. Ancak daha sonra ABD'nin yardımıyla İsrail toparlanmış ve Suriye ile Mısır'ı geri püskürtmüştür. Savaşın sonunda İsrail galip ayrılsa da Mısır ve Suriye'nin askeri başarıları önemlidir. Öte yandan, Sedat savaşın sonunda amacına ulaşmıştır. Mısır yıllar sonra ABD ile diplomatik temas kurmayı başarmıştır. ABD Dış İ̧̧leri Bakanı Kissenger'ın çabalarıyla İsrail Sina I ve Sina II antlaşmalarını imzalayarak işgal ettiği Sina Yarımadası'ndan çekilmiştir. 1975 yılına gelindiğinde Mısır buradaki alanları kontrol altına almış, kentleri yeniden inşa etmeye ve nüfuslandırmaya başlamıştır. ${ }^{3}$ ABD bu çalışmalar için Mısır'a ekonomik yardımlarda bulunmuştur. 1976 yılına gelindiğinde yapılan ekonomik yardım miktarı 750 milyon dolara ulaşmıştır. ${ }^{4}$

1973 Savaşı sonrası kurulan temaslar ve imzalanan antlaşmalar Camp David'e giden sürecin ilk adımları olarak görülebilir. Çünkü bu tarihten sonra Mısır, ABD ile yakınlaşmak ve ülkenin yörüngesini Batı'ya çevirmek adına çabalarını arttırmıştır. "İnfitah" adı verilen ekonomik liberalleşme programını yürürlüğe koymuştur. Nasır'ın Sosyalist ekonomi düşüncesinden uzaklaşılmıştır. Ancak bu durum sübvansiyonların da kaldırılmasıyla Mısır halkının ekonomik sıkıntılarının çoğalmasına ve halkın isyan etmesine neden olmuştur. Bu aşamada Sedat sorunları çözebilmek umuduyla İsrail ile barış için bir adım daha atmıştır. 1977 yılında Kudüs'e ziyarette bulunarak İsrail Parlamentosu'nda bir konuşma gerçekleştirmiştir. ${ }^{5}$

Sedat'ın konuşmasının ardından Mısır ve İsrail arasında barış görüşmeleri başlamıştır. Görüşmelere diğer Arap ülkeleri de dâhil edilmek istenmiş, ancak Arap ülkeleri buna yanaşmamıştır. Ekim 1978'de ABD'de Başkan Carter arabuluculuğunda bir araya gelen Misır ve İsrail liderleri yaklaşık iki hafta süren görüşmeler sonucunda Camp David Antlaşmalarını imzalamışlardır. Bu antlaşmalar Ortadoğu Barış Çerçevesi ve İsrail-Mısır Barış Çerçevesi olmak üzere iki sözleşmeden oluşmaktadır. İsrail-Mısır Barış Çerçevesi'ne göre iki ülke arasındaki ilişkiler normalleşecek, Sina tama-

3 Peter Mansfield, Ortadoğu Tarihi, (İstanbul: Say Yayınları, 2012), 414-418.

4 Cleveland, Modern Ortadoğu Tarihi, 419.

5 Cleveland, Modern Ortadoğu Tarihi, 421-422. 
men Mısır'in egemenliğine verilecekti. Bu sözleşmeye uygun olarak 1979 yılında İsrail-Mısır Barış Antlaşması imzalandı ve 1980'de karşı1ıklı büyükelçiler atand1. 1982 yılında ise İsrail Sina'dan tamamen çekilerek bölgeyi Mısır'ın egemenliğine bıraktı. Böylece İsrail-Mısır ilişkileri normalleşme içerisine girdi. Filistin meselesi ile ilgili olan diğer sözleşme Ortadoğu Barış Çerçevesi ise çok daha karışık ve belirsizdi. Bu sebepten dolayı bu sözleşme başarılı olamadı. ${ }^{6}$

\section{Sedat Dönemi: Camp David Sonrası ABD-Mısır}

Camp David sonrasında ABD ve Mısır arasındaki yakınlaşma giderek artmıştır. Ekonomik, sosyal, kültürel, siyasal, askeri, ticari vb. birçok alanda bu yakınlaşmanın yansımaları olmuştur. $\mathrm{Bu}$ alanlar içerisinde askeri alan en önemlilerinden birisidir. Antlaşmanın ardından $A B D$ ve Mısır üst düzey askeri yetkilileri arasında silahlanma konusunda bir taslak hazırlanması amaciyla görüşmeler başlatılmıştır. ${ }^{7}$

Mısır lideri Sedat ABD ile askeri alanda temas kurarak üç temel hedefe ulaşmayı istemiştir. Birincisi, Mısır'ın ABD'nin Ortadoğu stratejisi içerisinde merkezi bir konumda olduğunu Batı yanlısı Arap rejimlerine göstermektir. İkincisi, Sovyet yardımlarından yoksun kalan Mısır ordusunu ABD askeri yardımlarıyla memnun etmektir. Sedat bu sayede prestijini arttırmayı amaçlamıştır. Üçüncüsü ise, ABD'nin gözünde Mısır'ın önemli bir stratejik varlık olduğunu ispat etmektir. ${ }^{8}$ Diğer yandan, ABD'nin meseleye yaklaşımına da değinmek gerekmektedir. ABD bu askeri yardımların hem nitelik hem de nicelik olarak Misır'1 memnun etmesini ancak aynı zamanda İsrail'i de endişelendirmemesini hedeflemiştir. Bu nedenle, ABD'nin Mısır'a askeri yardımı Mısırlı liderleri tatmin edici düzeyde olmuş, ancak Mısır'ın İsrail'e karşı üstünlük kurabileceği düzeye de çıkmamıştır. ABD her daim bu dengeyi gözetmeyi bilmiştir. ${ }^{9}$

6 Mansfield, Ortadoğu Tarihi, 423-424.

7 Hermann Frederick Eilts, "The United States and Egypt," The Middle East: Ten Years After Camp David, ed., William B.Quandt, (Washington: Brookings Institutions, 1988), 143.

8 Ali E. Hillal Dessouki, "Egyptian Foreign Policy Since Camp David," The Middle East: Ten Years After Camp David, ed., William B. Quandt, (Washington, Brookings Institutions, 1988), 106-107.

9 Eilts, The United States and Egypt, 143. 
ABD ve Mısır'ın askeri alandaki iş birliği Camp David sonrası güçlenmiştir. Güvenlik Yardımı Programı ile birlikte Mısır, ABD'nin askeri yardım yaptığı ülkeler arasında ikinci sıraya yükselmiştir. 1982 yılına gelindiğinde Mısır'a dışarıdan yapılan askeri alandaki satışlar 900 milyon dolar seviyesine ulaşmıştır. Mısır'a verilebilecek askeri alandaki kredi miktarı 6 milyar dolar seviyesine çıkartılmıştır. Bunun dışında, ABD Mısır ordusuna askeri alanda teknik yardım da yapmaya başlamıştır. Çeşitli silah sistemleri ve programları kapsamında ABD'li bir grup uzman Misır ordusuna eğitim ve destek vermek üzere gönderilmiştir. Bunlardan birisi olan F4 uçakları ile ilgili program ${ }^{10}$ kapsamında 240'a yakın ABD'li uzmanın 1981 yılında Misır'da çalışmalarda bulunduğu ifade edilmiştir. M60 ${ }^{11}$ ve M113 ${ }^{12}$ araçları ile ilgili ortak eğitim programları gerçekleştirilmiştir. Ayrıca ortak hava savunma araştırmaları, lojistik sorunların giderilmesi adına çalışmalar ve dil eğitimi çalışmaları başlatılmıştır. ${ }^{13}$

Mısır-ABD arasında askeri alandaki ortak çalışmalardan bir diğeri ortak askeri tatbikat ve manevra konusunda olmuştur. 1980 yılında iki ordu Bright Star adı verilen ortak tatbikat çalışmasını gerçekleştirmiştir. Bu askeri tatbikatta ABD Hava Kuvvetleri'ne bağlı iki uçak ve 250 personel Mısır'daki Kina Hava Üssü çevresinde uçuşlar yapmıştır. Daha sonra ABD’nin Rapid Deployment Force ${ }^{14}$ (RDF) askeri grubu tatbikata katılmıştır. Bu çalışma RDF'nin (CENTCOM) Ortadoğu çöllerindeki ilk deneyimi olması sebebiyle önemlidir. Bright Star askeri tatbikatları daha sonraki yıllarda da yapılmaya devam etmiştir. ${ }^{15}$ Tatbikatlar ABD ve Mısır'ın bölgede yapacağ olası ortak operasyonların başarıya ulaşması adına önemlidir. Nitekim ilerleyen süreçte bu tatbikatların faydası görülmüştür.

101980 yılında ABD Mısır'a 35 adet F4 Savaş Uçağı satışı gerçekleştirmiştir. Bununla ilgili kaynak: Frank Barnaby, "A Frangible Peace." The Bulletin of The Atomic Scientists, Cilt 36, No 8, (Ekim 1980): 7. https://doi.org/10.1080/00963402.1980.1145 8763.

11 M60: ABD yapımı bir tank.

12 M113: ABD yapımı bir hafif zırhlı personel taşıyıcı araç.

13 Soheir A. Morsy, "U.S Aid to Egypt: An Illustration and Account of U.S. Foreign Assistance Policy,” Arap Studies Quarterly, Cilt 8, No 4, (Sonbahar 1986): 368.

14 Rapid Deployment Force: Hızlı İntikal Kuvveti ya da Çevik Kuvvet. 1979'da kurulan, 1983’te CENTCOM'a (U.S. Central Command) dönüşen kuvvet.

15 Dessouki, Egyptian Foreign Policy Since Camp David, 107. 
Sedat Dönemi (1979-1981) ABD'den Misır’a Silah Transferleri ${ }^{16}$

\begin{tabular}{|c|c|c|c|c|}
\hline Silah Türü & Silah Modeli & Sipariş Yılı & Sipariş Adet & Teslimat Yılı \\
\hline Nakliye Uçağ1 & $\mathrm{C}-130 \mathrm{H}$ & 1977 & 14 & $1979-1981$ \\
\hline İnsansız Hava Arac1 & Ryan-147 & 1977 & 12 & $1978-1979$ \\
\hline Hava Arama Radarı & TPS-43 & 1978 & 2 & 1980 \\
\hline BVRAAM $^{17}$ & AIM-7E Sparrow & 1979 & 70 & $1979-1980$ \\
\hline SRAAM $^{18}$ & AIM-9E Sidewinder & 1979 & 100 & 1979 \\
\hline SRAAM $^{19}$ & AIM-9J/P Sidewinder & 1979 & 250 & 1980 \\
\hline FGA $^{20}$ Uçăğ1 & F-4E Phantom 2 & 1979 & 35 & $1979-1980$ \\
\hline $\mathrm{APC}^{21}$ & M-113 & 1979 & 475 & $1979-1982$ \\
\hline $\mathrm{ASM}^{22}$ & AGM-65 Maverick & 1980 & 600 & 1980-1984 \\
\hline Anti-Tank Füze & BGM-71 TOW & 1980 & 1856 & $1980-1981$ \\
\hline $\mathrm{ARV}^{23}$ & M-578 & 1980 & 43 & 1980-1981 \\
\hline Tank & M-60 A3 Patton 2 & 1980 & 244 & 1981 \\
\hline Tank & M-60 A3 Patton 2 & 1980 & 67 & 1981 \\
\hline ARV & M-88 & 1980 & 43 & 1981-1982 \\
\hline $\mathrm{SAM}^{24}$ & I-HAWK & 1979 & 12 & $1982-1983$ \\
\hline Havan Taşıyıcı & M-106 & 1979 & 79 & 1982 \\
\hline SAM & MIM-23B HAWK & 1979 & 1000 & 1982-1983 \\
\hline FGA Uçağ1 & $\mathrm{F}-16 \mathrm{~A}$ & 1980 & 41 & 1982-1984 \\
\hline APC & M-113 & 1980 & 570 & $1982-1983$ \\
\hline Tank Yokedici & M-901 ITV & 1980 & 52 & 1983 \\
\hline
\end{tabular}

Kaynak: Stockholm International Peace Research Institute (SIPRI) Arms Transfer Databese, http://armstrade.sipri.org/armstrade/page/trade_register.php.

Askeri alandaki yakınlaşmanın dönemin siyasetine de yansımaları olmuştur. 1979 yılında SSCB' nin Afganistan'1 işgali ve sonrasında atılan adımlar buna örnek olarak verilebilir.

16 Tablo silahların sipariş yılı esas alınarak hazırlanmıştır.

17 BVRAAM (Beyond Visual Range Air-to-Air Missile): Görüş Ötesi Menzilli Havadan Havaya Füze

18 SRAAM (Short Range Air-to-Air Missile): Kısa Menzilli Havadan Havaya Füze

19 SRAAM (Short Range Air-to-Air Missile): Kısa Menzilli Havadan Havaya Füze

20 FGA (Fighter Ground Attack): Karaya Saldırı Savaş Uçağı

21 APC (Armored Personnel Carrier): Zırhlı Personel Taşıyıcı Aracı

22 ASM (Air-to Surface Missile): Havadan Karaya Füze

23 ARV (Armored Vehicle): Zırhlı Araç

24 SAM (Surface to Air Missile): Karadan Havaya Füze 
Soğuk Savaş yıllarında yaşanan bu gelişme sonrası ABD Afganistan'ın "SSCB'nin Vietnam'ı" haline gelmesi adına "Yeşil Kuşak Projesi" olarak bilinen projeyi devreye sokmuştur. Bu proje kapsamında İslam'ın "cihat" söylemini ön plana çıkaran ABD Afganistan'daki İslami silahlı gruplara her türlü desteği sağlamış ve SSCB'yi Afganistan'da zor duruma düşürmeyi hedeflemiştir. ABD projeyi yürütürken Pakistan ve Suudi Arabistan başta olmak üzere birçok ülkeden de destek almıştır. ${ }^{25}$ Misır da bu ülkelerden birisi olmuştur. ABD politikaları dâhilinde silahlandırılan bu gruplara Misır ordusu tarafından lojistik destek verilmiştir. ${ }^{26} 1980$ 'li yıllar boyunca devam eden Afganistan'daki mücadelede Mısır Ordusu'nun sağlamış olduğu bu destek ABD politikalarına uygun bir biçimde hareket ettiğine verilebilecek örneklerden bir tanesidir.

Mısır-ABD askeri yakınlaşmasının siyaset sahasındaki bir diğer yansımas1 İran Rehine Krizi döneminde görülmüştür. 1979 İran Devrimi sonras1 ABD diplomatik temsilciliğinin İranlı devrimci gruplar tarafından basılması ve bir grup Amerikan vatandaşının rehin alınması $\mathrm{ABD}$ hükümetini zor durumda bırakmıştır. Bu süreçte ABD rehin alınan vatandaşlarını kurtarmak adına 1980 yılında bir operasyon yapma kararı almıştır. Gerçekleştirilen bu operasyon sırasında Mısır ile askeri yönden iş birliğine gidilmiş, Mısır kendi askeri tesislerini ABD'nin kullanımına açmıştır. ${ }^{27}$ Her ne kadar operasyon başarısız olsa da, Mısır-ABD yakınlaşmasını öne çıkaran ve Mısır'ın ABD politikalarıyla uyumlu hareket ettiğini gösteren önemli gelişmelerden birisi olarak görebilir.

ABD'nin Mısır'a yaklaşımında ordu üzerinden bir ilişki geliştirmesinin temel sebebi ordunun rejim içerisindeki merkezi konumudur. Mısır'da ordu yalnızca siyaset ve güvenlik alanında değil, ekonomik alanda da söz sahibidir. Özellikle 1970’lerin sonlarından itibaren ordunun ekonomik alandaki etkinliği giderek artmıştır. Camp David Antlaşmaları ile birlikte en önemli

25 Mehmet Şahin, “ABD’nin ‘Müslüman' Savaşçıları,” Akademik Ortadoğu, Cilt 3, Say1 1, (2008): 44-46.

26 William B. Quandt, The United States and Egypt: An Essay on Policy for 1990's, (Washington: Brookings Institutions, 1990), 33.

27 Abdul Monem Said Aly, "Egypt: A Decade After Camp David," The Middle East: Ten Years After Camp David, ed., William B.Quandt, (Washington: Brookings Institutions, 1988), 65. 
dış tehdidin ortadan kalkmasıyla ordunun iç siyasette etkinliğini arttırmaya ve kurumsallaşmaya yöneldiği ifade edilmektedir. İlk olarak 1978 yılında Arap Organizasyonu kuruluşu adı altında savunma sanayi alanında üretim çalışmaları başlatılmıştır. ${ }^{28}$ Aynı dönemde Sedat'ın liberalleşme programı ile birlikte ordu için ekonomide bir rant kapısı açılmıştır. Mısırlı bazı subaylar ülkeye yatırım yapan yabancı şirketlere danışman olmuş ve böylece ekonomiye etki etme şansı elde etmişlerdir. Diğer yandan, ordu ekonomik alanda birçok sektöre doğrudan girişimci olarak katılmıştır. Mısırlı subaylar aracılığıyla silah üretiminden tarım ve gıda sektörüne, elektronik eşyadan havacılık ve turizme, Petro-kimya endüstrisinden ilaç sanayisine kadar birçok sektörde faaliyet göstermeye başlamıştır. 1979 yılında kurulan Ulusal Hizmet Projeleri Örgütü ve 1981 yılında kurulan Sivil Projeler Örgütü ordunun ekonomik alandaki etkinliğini arttırmak amacıyla başlatılan girişimlerdir. $\mathrm{Bu}$ girişimler ile ordunun ekonomik faaliyetleri elektrik üretimi, su idaresi, yol, köprü, telekomünikasyon gibi altyap1 yatırımları dâhil temel kamusal hizmet alanlarına da yayılmıştır. Mübarek döneminde ordunun ekonomik faaliyet alanı daha da genişleme imkânı bulmuştur. Bu süreçte devlet imtiyazlarından ve çeşitli sübvansiyonlardan da yararlanan ordu Mısır içerisinde bir çeşit ticari-iktisadi krallık haline gelmiştir. Vergi muafiyeti, hazineye ödeme yapmadan müsadere etme hakk1, döviz kuru ve tercihli gümrüklerden yararlanma bu devlet imtiyazlarından bazılarıdır. Ordunun en önemli imkânlarından bir diğeri askere alınan erlerin ucuz iş gücü olarak çalıştırılabilmesidir. Erler üç yıllık askerlik süreleri boyunca önce eğitim-öğretim süreçlerinden geçirilmekte, daha sonra da orduya ait fabrikalarda çalıştırılmaktadırlar. Bu durum serbest piyasa içerisinde haksız bir rekabete yol açmakta ve Misır ekonomisinde özel teşebbüsün gelişmesini önlemektedir. Ordunun yararlandığ 1 devlet imkânlarından bir diğeri askeri bütçe üzerinde etkili bir denetimin yapılamamasıdır. Ordunun yaptığı harcamaların devlet denetiminin dışında bırakılması yolsuzluk ve usulsüzlük şüphelerini de beraberinde getirmektedir. ${ }^{29}$ Camp David antlaşmaları ile başlayan barış ortamında ordu ülke içerisinde etkinliğini arttırma firsatı bulmuştur. Özellikle ekonomik alanda etkinliğini arttıran ordu ülke

28 Mohammed Moussa, "Kışla, Ekonomi ve Siyaset Üçgeninde Mısır Ordusu," Ortadoğu'da Ordu ve Siyaset, ed., Veysel Kurt, (İstanbul: Seta Yayınları, 2017), 90.

29 Abdul Rezak Bilgin, Arap Baharı Sürecinde Orduların Tutumu: Misır, Libya ve Tunus Örnekleri, (Ankara: Birleşik Yayınları, 2014), 109-124. 
ekonomisinde başat aktör haline gelmiştir. ${ }^{30}$ Misır ordusunun ekonomideki kontrolünün \%15-40 aralığında olduğu tahmin edilmektedir. ${ }^{31}$

Rejim içerisinde merkezi bir konuma sahip olan ordu siyasi-idari karar alma mekanizmalarına da tesir etmektedir. Nasır, Sedat ve Mübarek dönemlerinde ordunun bu alanlardaki karar alma süreçlerinde başat rolü olduğu ifade edilmektedir. Değişen şartlara göre bu rol her bir liderin döneminde farklı düzeylerde etkisini göstermiştir. ${ }^{32}$ Nasır döneminde ordunun hem siyasette hem de bürokraside doğrudan yönetimde ağırlığı söz konusu olmuştur. Kabinede asker kökenli bakanların oranı \%65 seviyesine ulaşırken, bürokraside asker kökenli şahıslar çok sayıda pozisyonda görev almışlardır. ${ }^{33}$ Asker kökenli isimler Başkanlık, Başbakanlık, Başkan Yardımcılıkları, kritik bazı Bakanlıklar gibi önemli stratejik pozisyonları kontrol etmişlerdir. Diğer yandan bu dönemde Arap Sosyalist Birliği Yürütme Komitesi'nin \%56's1, valilerin \%80'inden fazlası asker kökenli olmuştur. ${ }^{34}$ Doğrudan Mısır Devlet Başkanı'na bağlanan valiler aracılığıyla Nasır iktidarını merkezileştirecek bir yapı oluşturmuştur. Mısır'1 1960 yılında 26 yerel valilik şeklinde organize etmiştir. Bu yapının yürütücüsü olarak da ordudaki subayları belirlemiştir. Bir başka deyişle, valileri ordudaki subaylar içerisinden seçerek orduya idare mekanizmasında başat bir rol vermiştir. ${ }^{35}$ Sedat döneminde ise ordunun profesyonel hale geldiği belirtil-

30 Ordunun ekonomide ağırlığının artması bu dönemde belli çevreler tarafından eleştiriye tabi tutulmuştur. Örneğin; Müslüman Kardeşler hareketi 80'li yıllarda ordunun bu artan etkisine ve yaşanan yolsuzluklara belli ölçülerde eleştiri getirmiştir. 1987'de kurulan Sosyalist İşçi Partisi ve Liberal Parti ittifakının seçim programı bu açıdan önemlidir. $\mathrm{Bu}$ ittifaka kendi ismiyle resmi olarak katılması yasak olan Müslüman Kardeşler hareketi de destek vermiştir. İslami İttifak adıyla bilinen üçlü koalisyonun programında ekonomik yapı eleştiriliyor, yolsuzluklar gündeme getirilerek ekonomi politikalarında reform talep ediliyordu. Ayrıntılar için bakınız: Steven Cook, Yönetmeden Hükmeden Ordular, (İstanbul: Hayy Kitap, 2008), 191-197.

31 Sherine Tadros, "Egypt military's economic empire," 16 Şubat 2012, Al Jazeera English, https://www.aljazeera.com/indepth/features/2012/02/2012215195912519142.

32 Edip Asaf Bekaroğlu ve Veysel Kurt, "Mısır'da Otoriter Rejimin Sürekliliği ve Ordu: 'Arap Baharı' ve Sonrası Sürecin Analizi," Türkiye Ortadoğu Çalışmaları Dergisi, Cilt 2, Say1 2, (2015): 10-11.

33 Bekaroğlu ve Kurt, "Misır," 12-13.

34 Ibrahim A. Karawan, "Egypt," The Political Role of the Military: An International Handbook, Ed. Constantine P. Danopoulos ve Cynthia Watson, (Westport: Greenwood Press, 1996), 108.

35 Yezid Sayigh, "Above the State: The Officers Republic in Egypt," Carnegie Middle East Center, Ağustos 2012, http://carnegieendowment.org/files/officers_republic1.pdf, 13. 
mektedir. Bu dönemde ordunun siyasetteki görünürlüğü azalsa da sistem içerisindeki ağırlığı varlığını sürdürmüştür. ${ }^{36}$ Üst düzey askerler kabinede ve iktidar partisinin yönetim kurulunda, sayıları sivillerden daha az olsa da yer almaya devam etmiştir. ${ }^{37}$ Sedat kabinedeki askerlerin oranını azaltarak \%13 seviyesine düşürmüştür, 1963 yılında sayıları 24 olan asker kökenli valilerin sayısını 1980 yılında 5'e indirmiştir. Sedat döneminde ordu yukarıda söz edilen ekonomik yatırımlara yönelerek bu alanda etkin bir aktör olarak ön plana çıkmıştır. ${ }^{38}$ Mübarek dönemine bakıldığında da ordunun sistemdeki ağırlığı görülmektedir. Bu dönemde çok sayıda emekli asker devlet bürokrasisinde yüksek pozisyonlara atanmıştır. 2011 yılında ülkedeki asker kökenli valilerin sayısı 18 'e ulaşmıştır. Üstelik bürokrasideki bu pozisyonların kilit noktalarda olduğu ifade edilmektedir. Kızıldeniz'deki limanların müdürleri, Süveyş Kanalı'ndan sorumlu müdür bu kilit noktalara örnek olarak verilebilir. ${ }^{39}$ Ordu-Siyaset ilişkisini güçlendiren bir diğer unsur da Cumhurbaşkanı'nın niteliğidir. Devrim sonrası yaklaşık bir yıl bu görevi yürüten Mursi dışında Mısır'ın bütün cumhurbaşkanları asker kökenlidir. Her ne kadar belli dönemlerde cumhurbaşkanları ile ordu arasında sorunlar yaşansa da genel itibariyle iki kurum arasında kritik ve yakın bir iş birliğinin olduğu vurgulanmaktadır. Cumhurbaşkanı'nın kendi içlerinden biri olması askeri kurumun ona güven duymasını sağlamaktadır. Bu yakınlık sayesinde subaylar ihtiyaç duydukları anda cumhurbaşkanı ile doğrudan temas kurarak siyasete etki edebilmektedirler. ${ }^{40}$ Diğer yandan, sıklıkla başvurulan olağanüstü hal uygulaması ile birlikte ülke genelinde askerin yetkileri arttırılmaktadır. Bu uygulama çerçevesinde sivillerin askeri mahkemelerde yargılanması "meşrulaştırılmakta" ve terörizm suçlamaları üzerinden sivil muhalefet unsurları -özellikle İslamcılar- bastırılmaktadır. Devlete komplo kurmak vb. suçlarla askeri mahkemelerin sivilleri yargıla-

36 Bekaroğlu ve Kurt, "Misır," 14.

37 Raymond A. Hinnebusch Jr., Egyptian Politics Under Sadat, (Cambridge: Cambridge University Press, 1985), 131.

38 Bilgin, Arap Baharı Sürecinde Orduların Tutumu: Mısır, Libya ve Tunus Örnekleri, 109.

39 Zeinab Abul-Magd, "The Egyptian military in politics and the economy: Recent history and current transition status," CMI Insight, Ekim 2013, Say1 2, https://www. cmi.no/publications/file/4935-the-egyptian-military-in-politics-and-the-economy.pdf,, 2.

40 Steven Cook, Yönetmeden Hükmeden Ordular, (İstanbul: Hayy Kitap, 2008), 181183; Roger Owen, State, Power \& Politics in The Making of the Modern Middle East, (Londra ve New York: Routledge,1992), 204. 
ması ordunun içerideki mevcut varlı̆̆ını kuvvetlendirmektedir. Bir başka deyişle, olağanüstü hal uygulaması ile birlikte askerin yargı üzerinden siyasete etkisi (sivil grupların tasfiyesi vb.) arttırılmaktadır. ${ }^{41}$ Ordunun sahip olduğu güçlü nüfuz düşünüldügünde siyasi iktidarı doğrudan eline alıp almayacağ1 sorusu önemlidir. Bu hususta yaygın görüş ordunun iktidarı almaya ihtiyacının olmadığı yönündedir. Çünkü hâlihazırda kendisi oradadır ve perde arkasından da olsa siyasi süreçlerde kritik bir role sahiptir. Bölgesel ve uluslararası düzeyde "ülkenin ulusal güvenliğì" ve birtakım hedeflerinin belirlenmesi noktasında söz sahibi olduğu belirtilmektedir. ${ }^{42}$

Bütün bunlar Mısır ordusunun devlet yapısı içerisindeki konumunu görebilmek açısından önemlidir. Bununla birlikte ABD'nin Mısır politikasında neden orduyu merkeze aldığını ve neden ilişkilerin askeri boyutuna özel önem atfettiğini anlamak açısından oldukça kritiktir.

\section{Hüsnü Mübarek Dönemi: Silah Alımları, Statü, Ortak Tatbikat ve Operasyonlar}

Sedat'ın 1981 y1lında ölümünden sonra Hüsnü Mübarek Mısır'ın lideri olmuştur. Sedat döneminin sonlarında başlayan ABD-Mısır yakınlaşmas1, Mübarek döneminde de devam etmiştir. 2011 Devrimi'ne kadar devam eden 30 yıllık Mübarek iktidarında askeri alanda Mısır giderek ABD'ye bağımlı hale gelmiştir. Bu bağımlılığın merkezinde de ordu yer almaktadır. ABD Mısır ile askeri bakımdan sıkı ilişkiler tesis etmeyi ve bu sayede de bölge politikalarında ihtiyaç duyduğu anda uyum içerisinde çalışabileceği bir müttefik ordu kazanmayı hedeflemiştir. Mübarek döneminde de bu amaç çerçevesinde hareket edilmiş ve başarıya ulaşı1mıştır.

1980'lerin ortalarından itibaren askeri yardımlar artarak devam etmiştir. Önce F4 daha sonra F16 savaş uçakları Mısır ordusuna verilmiştir. Bunlar dışında tanklar, zırhlı personel taşıyıcı araçları, hava savunma füzeleri, ağır silahlar ile çok sayıda ekipman da teslim edilmiştir. Bu araçların eğitimi konusunda da çalışmalar yapılmıştır. Bütün bu askeri yardımlar Kahire'deki Amerikan Askeri İş birliği Ofisi tarafından koordine edilmiştir. Ayrıca

41 Cook, Yönetmeden Hükmeden Ordular, 76, 180.

42 Nazih N. Ayubi, Over-Stating The Arab State: Politics and Society in the Middle East, (Londra ve New York: I. B. Tauris Publishers, 1995), 261-273. 
bu süreçte Misır ordusundaki subaylardan Mareşal Muhammed Abd alHalim Abu Ghazalah ön plana çıkmıştır. Daha önce Washington'da Mısır Askeri Ataşesi olarak görev yapan Abu Ghazalah, bu dönemde hükümette görev alarak sürecin yürütülmesine katkıda bulunmuştur. Savunma Bakanı olarak görev yapan Ghazalah'nın ABD ile geçmişten gelen yakınlığı büyük fayda sağlamıştır. ${ }^{43}$

ABD güvenlik alanında iş birliği içerisinde olduğu ülkeler ile çeşitli programlar kapsamında ortaklık geliştirmiştir. $\mathrm{FMS}^{44}$, $\mathrm{FMF}^{45}$ ve IMET ${ }^{46}$ programları bu alanda öne çıkan programlar olmuşlardır. Mısır da bu yakınlaşma sürecinde bu programlar içerisine dâhil edilmiş, iki ülke arasındaki güvenlik iş birliği bu girişimler aracılığıyla sağlanmıştır. FMS programı savunma silahları satışıyla ilgilenirken, FMF ise askeri alanda verilecek kredi ve hibeler ile ilgilenmiştir. IMET programı ise Misırlı subay adaylarının ABD'de eğitim alması adına çalışmalar yürütmüştür. IMET kapsamında ABD'ye gönderilen öğrenciler Ulusal Savunma Üniversitesi ve $\mathrm{CGSC}^{47}$ gibi önemli askeri merkezlerde eğitim alma imkânına sahip olmuşlardır. ${ }^{48}$ FMF ve IMET yardımları Mısır ile güvenlik iş birliği konusunda en kalıcı ve geniş kaynakları sağlayan programlardır. 1979 yılında hemen Camp David sonras1 1,5 milyar dolar seviyesinde olan FMF, 1981'de 550 milyon dolara düşürülmüsstür. Ancak 1987 yılında 1,3 milyar dolar düzeyine sabitlenmiştir. Bu tarihten itibaren her y1l ABD tarafından Mısır'a 1,3 milyar dolarlık yardım FMF kapsamında verilmektedir. Diğer yandan ortalama 1,3 milyon dolar düzeyinde bir yardım da IMET program1 kapsamında yapılmaktadır. ${ }^{49}$ FMF programı kapsamında yapılan yardımlar üç farklı kategoride değerlendirilmektedirler. Buradan gelen paranın

43 Eilts, The United States and Egypt, 144.

44 FMS: Foreign Military Sales

45 FMF: Foreign Military Financing

46 IMET: International Military Education and Training

47 CGSC: Command and General Staff College

48 Susan S. Vogelsang, "U.S.-Egypt Security Cooperation after Egypt's January 2011 Revolution," U.S. Department of State, 2011, http://www.dtic.mil/dtic/tr/fulltext/u2/ a557655.pdf, 18-19.

49 Daniel L. Tavana, "U.S. Security Assistance to Egypt: Military Aid and Legislative Conditionality," (Cenevre Silahlı Kuvvetler Demokratik Kontrol Merkezi-DCAF tarafindan düzenlenen konferansta sunulan çalışma, Montrö, 2-4 Nisan 2014), https:// www.observatoire-securite.tn/wp-content/uploads/sites/4/2016/11/Egypt-CivilMilitary-Relations-Conference-Paper-Series.pdf, 6. 
yaklaşık \%30'u ile yeni silahlar satın alındığı, yaklaşık \%15'i ile var olan silahların gelişiminin sağlandığı ve yaklaşı \% 020 'si ile devam eden destekbakım sözleşmelerine yatırım yapıldığ 1 ifade edilmektedir. ${ }^{50}$

50 Jeremy M. Sharp, "Egypt: January 25 Revolution and Implications for U.S Foreign Policy," CRS Report for Congress, 11 Şubat 2011, http://www.refworld.org/pdfid/4d6 f4dc5c. pdf, 29; Thalif Deen, "Egyptian Army's Firepower Overwhelmingly U.S.-Supplied," IPS Haber Ajans1, 9 Temmuz 2013, http://www.ipsnews.net/2013/07/egyptian-armys-firepoweroverwhelmingly-u-s-supplied/. 


\section{Mübarek Dönemi ${ }^{51}$ (1981-2010) ABD'den Mısır’a Silah Transferleri}

\begin{tabular}{|c|c|c|c|c|c|c|}
\hline & & \multicolumn{5}{|c|}{ Satın Alınan Silah Sayısının Yıllara Göre Dağı̆ımı (Adet) } \\
\hline Silah/Sistem Türü & Silah/Sistem Modeli & 1981-1985 & $1986-1990$ & 1991-1995 & $1996-2000$ & 2001-2010 \\
\hline Anti-Tank Füze & BGM-71 TOW & 2400 & 3500 & 695 & 2372 & 8956 \\
\hline Tassıyıcı Hava Aracı & C-130H Hercules & 3 & 3 & - & - & 3 \\
\hline FGA Ucağ 1 & $\mathrm{~F}-16 \mathrm{C}$ & 40 & 47 & 46 & 45 & - \\
\hline Tank & M-60A3 Patton-2 & 442 & 700 & 340 & 34 & - \\
\hline ARV & M- 88 & 201 & 56 & - & - & - \\
\hline Hava Arama Radarı & TPS-63 & 50 & - & - & - & - \\
\hline BVRAAM & AIM-7M Sparrow & 300 & 282 & - & 271 & - \\
\hline SRAAM & AIM-9L/M Sidewinder & 750 & 560 & - & 314 & 414 \\
\hline Hafif Helikopter & Hiller-12/OH-23 Raven & 20 & - & - & - & - \\
\hline Kendinden İtmeli Top & M-109A1 $155 \mathrm{~mm}$ & 164 & - & - & - & 401 \\
\hline Hafif Zırhlı Mühimmat Tasılvıc1 Arac1 (ALV) & M-992 FAASV & 51 & - & - & - & - \\
\hline ASW Sonar & DE-1167 & 2 & - & - & - & - \\
\hline $\begin{array}{c}\text { Havadan Erken Uyarı ve Kontrol (AEW\&C) } \\
\text { Arac1 }\end{array}$ & E-2C Hawkeye & 5 & 1 & - & - & 2 \\
\hline APC & M-113 & 592 & 123 & 166 & 422 & 284 \\
\hline Anti-Gemi Füze & RGM-84 Harpoon & 16 & 58 & 52 & 74 & - \\
\hline Devriye Gemisi & Swiftships-93 & 9 & - & - & - & 2 \\
\hline Hava Arama Radar1 & Trackstar & 7 & 7 & - & - & - \\
\hline SRAAM & AIM-9J/P Sidewinder & 5000 & - & - & - & - \\
\hline Mobil SAM Sistemi & M-48 Chaparral & 26 & 25 & - & 130 & - \\
\hline SAM & MIM-72C Chaparral & 450 & 432 & - & 1072 & - \\
\hline Hava Arama Radarı & TPS-59 & 4 & 9 & 1 & 5 & - \\
\hline Sinyal İstihbarat (SIGINT) Hava Arac1 & Beech-1900 SIGINT & 6 & 2 & - & - & - \\
\hline FGA Uçağ1 & F-16A & 1 & - & - & - & - \\
\hline APC & M-992 FDCV & 72 & - & - & - & - \\
\hline Insansız Hava Aracı (IHA-UAV) & R4E Skyeye & 48 & - & - & - & - \\
\hline IHA & Scarab & 52 & - & - & - & - \\
\hline Reconnaissance Keșif Hava Aracı (AV) & Commando Scout & - & 112 & - & - & - \\
\hline Gösterisli Radar & TPQ-37 Firefinder & - & 2 & - & - & - \\
\hline Kendinden Itmeli Top & $\mathrm{M}-109 / \mathrm{SP}-122122 \mathrm{~mm}$ & - & 76 & - & 48 & - \\
\hline Tank & M-1A1 Abrams & - & 524 & - & 131 & 350 \\
\hline ASM & AGM-65 Maverick & - & 144 & 354 & & \\
\hline Hava Elektro-Optik Sistemi & AAQ-14 LANTIRN & - & 12 & 24 & 15 & - \\
\hline Hava Elektro-Optik Sistemi & AAQ-20 Pathfinder & - & 12 & - & - & - \\
\hline SAM & MIM-23B HAWK & - & 150 & - & 180 & - \\
\hline Anti-Tank Füze & AGM-114A Hellfire & - & 492 & - & 927 & - \\
\hline Savas Helikopteri & AH-64A Apache & - & 24 & 12 & 25 & - \\
\hline Tașinabilir SAM & FIM-92 Stinger & - & 100 & - & 600 & 764 \\
\hline Mayına Karșı Onlemler (MCM) Gemisi & Swiftships MCM & - & 3 & - & - & - \\
\hline MCM Gemisi & Swiftships RSV & - & 2 & - & - & - \\
\hline Turbofan & F110 & - & - & 8 & - & - \\
\hline FGA Uçağ1 & F-4E Phantom-2 & - & - & 1 & - & - \\
\hline Firkateyn & Knox & - & - & 2 & - & - \\
\hline ASW Torpido & Mk-46 Mod-5 NEARTIP & - & - & 80 & 150 & - \\
\hline Savas AC Radarı & AAQ-13 LINTERN & - & - & 24 & 15 & - \\
\hline ASW Helikopter & SH-2G Super Seasprite & - & - & 10 & - & - \\
\hline Tank Yokedici & M-901 ITV & - & - & 130 & - & - \\
\hline Hafif Ucak & Commander-114B & - & - & - & 6 & - \\
\hline SAM Sistemi & I-HAWK & - & - & - & 8 & - \\
\hline Havan Tassıyıcı & M-106 & - & - & - & 15 & - \\
\hline Uçaksavar & M-167 Vulcan & - & - & - & 66 & - \\
\hline AEW Radar & APS- 145 & - & - & - & $\frac{5}{5}$ & - \\
\hline Turbofan & TFE-371 & - & - & - & 80 & - \\
\hline Mobil AD Sistem & Avenger & - & - & - & 25 & 25 \\
\hline Gösterișli Radar & TPQ-36 Firefinder & - & - & - & 6 & - \\
\hline Coklu Frrlatma Roketi (MRL) & M-270 MLRS $227 \mathrm{~mm}$ & - & - & - & - & 38 \\
\hline ARV & M-88A2 Hercules & - & - & - & 50 & 37 \\
\hline Nakliye Helikopteri & CH-47D Chinook & - & - & - & 4 & - \\
\hline Dizel Motor & AVDS- 1790 & - & - & - & 30 & 260 \\
\hline SAM & RIM-66B Standart-1MR & - & - & - & 216 & 22 \\
\hline Firkateyn & Perry & - & - & - & 4 & - \\
\hline Yakın Silah Sistemi (CIWS) & Mk-Phalanx & - & - & - & - & 4 \\
\hline Hava Arama Radarı & SPS-48E LBR & - & - & - & - & 6 \\
\hline AVP & HMMWV ${ }^{9}$ Up-Armoured & - & - & - & - & 100 \\
\hline Anti-Gemi Füze & RGM-84L Harpoon & - & - & - & - & 25 \\
\hline SAM & RIM-116A RAM & - & - & - & - & 139 \\
\hline Güdümlü Bomba & Paveway & - & - & - & - & 50 \\
\hline Turbofan & TFE-731 & - & - & - & - & 40 \\
\hline Koruyucu & Swiftship-86 & - & - & - & - & 6 \\
\hline Mayın Temizleyici & Osprey & - & - & - & - & 2 \\
\hline Korvet & Ambassador & - & - & - & - & 3 \\
\hline Ucak Kesif Sistemi & DB-110 & - & - & - & - & 1 \\
\hline FGA Uçağ1 & F-16 Block-50/52 & - & - & - & - & 20 \\
\hline ASW Sonar & LFATS & - & - & - & - & 2 \\
\hline
\end{tabular}

Kaynak: Stockholm International Peace Research Institute (SIPRI) Arms Transfer Databese, http://armstrade.sipri.org/armstrade/page/trade_register.php.

51 Tabloda silah satışları sipariş yılı esas alınarak hazırlanmıştır. Mübarek 2011'in başında iktidardan düştüğü için tablodaki satışlar 2011 yılını içermemektedir. 
Dikkatle incelenmesi gereken bir diğer husus ABD'li subaylar ile Misırlı subaylar aralarındaki iletişimdir. Mısır bir dönem askeri alandaki tedarikinin büyük bir bölümünü SSCB'den sağlamıştır. Bu yıllarda Sovyet Rusya ile kurulan temasın Mısırlı subayların siyasi görüsslerini etkilediği ve orduda Amerikan karşıtlığını güçlendirdiği ifade edilmektedir. ${ }^{52} 1980$ 'lerde ise ABD ile ilişkilerin giderek güçlenmesi ve özellikle askeri alanda temasların arttırılmasının ordunun siyasi çizgisinde de bir değişim yarattığ söylenebilir. Bu noktada 1996 yılından itibaren her yıl 600'e yakın Mısır11 subayın ABD'de eğitim almasına dikkat çekmek gerekmektedir. 2013 yılında Mursi'yi deviren darbenin lideri General Sisi de bu subaylar içerisindedir. ${ }^{53}$ Yukarıda bahsedilen IMET programı kapsamında yetişen bu subaylar ile birlikte ordudaki ABD etkisinin giderek arttığı ifade edilebilir. Böylece ABD'nin bölge politikalarında uyum içerisinde çalışabileceği bir subay kadrosu oluşturulmuştur.

1988 y1lına gelindiğinde ABD yönetimi Mısır konusunda yeni bir hamle daha yapmıştır. Bu yıl içerisinde Mısır'a "Nato-Dışı Müttefik" (NonNATO Ally) statüsü verilmiştir. Bu sayede iki ülke arasındaki yakınlaşmayı arttırmak ve ilişkileri daha üst seviyeye çıkarmak hedeflenmiştir. ${ }^{54}$ Ayrıca, yukarıda bahsedilen, 1987 yılında mali yardımların 1,3 milyar dolar seviyesine sabitlenmesini de bu noktada hatırlatmak yerinde olacaktır. 1980'lerin sonunda yaşanan bu gelişmeler küresel gelişmelerden ayrı olarak düşünülmemelidir. Soğuk Savaş'ın sonuna gelinirken ABD dikkatini Ortadoğu bölgesine yoğunlaştırmıştır. Bu kapsamda Mısır ile ilişkilerini farklı bir boyuta taşıyarak Ortadoğu politikalarında ordusu güçlü olan önemli bir müttefik kazanmayı amaçladığı ifade edilebilir.

NATO-Dışı müttefik statüsü ile Mısır son teknoloji silahları temin etme imkânını elde etmiştir. Aynı yıl ABD hükümeti Mısır'a 555 adet tank ve 144 adet Maverick adlı havadan-karaya füze satışı yapacağını kongreye bildirmiştir. Bu dönemde ilişkilere gölge düşürecek birtakım hadiseler de yaşanmıştır. Temmuz ayında Amerikan vatandaşı bir Mısırlı ABD füze parçalarını çalmak ve gizlice Mısır'a sokmaya çalışmak ile suçlanarak tu-

52 Quandt, The United States and Egypt: An Essay on Policy for 1990's, 34.

53 Ahmed Shibab Eldin, "Egypt's American-Made Military: More Mistakes Than Morsi," Huffington Post, https://www.huffingtonpost.com/ahmed-shihabeldin/egyptsamericanmade-milit_b_3549340.html.

54 Aly, Egypt: A Decade After Camp David, 65. 
tuklanmıştır. ${ }^{55} 1989$ yılında Mısır Devlet Başkanı Mübarek ABD ile yakın ilişkileri olan Savunma Bakanı Ghazalah'yı görevden alarak daha düşük bir pozisyon olan Başkan Yardımcılığı'na atamıştır. Yine 1989 yılında ABD basını Mübarek'i kimyasal silahlar üretmek ile itham eden yayınlar gerçekleştirmiş, Mübarek bu suçlamaları reddetmiştir. ${ }^{56} \mathrm{Bu}$ gelişmeler ilişkilere gölge düşürmüş ancak daha sonraki gelişmeler Mısır-ABD ortakl1ğını yeniden güçlendirmiştir.

Mübarek döneminde Misır'ın ve Misır ordusunun ABD'nin bölge politikalarına uygun hareket ettiğini gösteren en önemli örneklerden birisi Körfez Savaşı'dır. 1990 yılında Saddam Hüseyin yönetimindeki Irak'ın Kuveyt'i işgal etmesi uluslararası alanda bir krize neden olmuştur. Körfez Krizi olarak da bilinen bu kriz sonrası ABD konuya müdahil olarak Irak'a karşı bir ortak operasyon düzenlenme kararı almıştır. Suudi Arabistan, Katar, Birleşik Arap Emirlikleri, Suriye, Umman, Bahreyn, Fas gibi ülkelerin bulunduğu uluslararası koalisyona Mısır da katılmıştır. Mısır ordusu göndermiş olduğu 35.000 kişilik birliğiyle Çöl Kalkanı ve Çöl Fırtınası operasyonlarına destek veren ülkeler arasında en çok birlik gönderen dördüncü ülke olmuştur. Mısır bunun karşıllğını savaşın bitiminde almış ve ülke dış borçlarının 20 milyar dolarlık kısmı silinmiştir. ${ }^{57}$ Krizin ardından ABD ve Mısır ordusu subayları iki ülke arasında gerçekleştirilen Bright Star ortak askeri tatbikatlarının Çöl Fırtınası operasyonunda ordular arasındaki uyumu kolaylaştırdığını vurgulamışlardır. Ayrıca Bright Star ve Çöl Fırtınasının gelecekteki Mısır-ABD ortak girişimleri adına başarılı iki örnek olduğunu belirtmişlerdir. ${ }^{58}$ Nihayetinde ABD ve Mısır' 1 n askeri alanda kurmuş olduğu ilişkilerin ABD'nin bölge politikalarının başarıya ulaşması noktasında ciddi katkısının olduğu Körfez Krizi sırasında da görülmüştür.

55 Hadise hakkında o dönem yayınlanan haber için bkz: "U.S. Accuses 2 Egyptian Colonels In Plot to Smuggle Missile Material," New York Times, 25 Haziran 1988, http://www.nytimes.com/1988/06/25/world/us-accuses-2-egyptian-colonels-in-plotto-smuggle-missile-material.html?pagewanted=all.

56 Europa Publications, The Middle East and North Africa 1997, (London: Europa Publications, 1997), 383.

57 Steven A.Cook, The Struggle for Egypt: From Nasser to Tahrir Square, (New York: Oxford University Press, 2012), 161.

58 Jeremy M. Sharp, “Egypt-United States Relations," CRS Issue Brief for Congress, 15 Haziran 2005, http://www.au.af.mil/AU/AWC/AWCGATE/crs/ib93087.pdf, 14. 
1996 yılında ABD Savunma Bakanı Mısır'a ziyarette bulunmuş ve burada ABD'nin Mısır'a gelişmiş askeri ekipman yardımı yapacağını ve 21 adet F16 uçağının da bu paket içerisinde yer alacağını duyurmuştur. ${ }^{59}$ İki ülke arasındaki yapılan silah antlaşmalarına bir yenisi daha eklenmiştir. Silah antlaşmaları 1979 yılı öncesi ve sonrası iki ülke arasındaki ilişkilerin askeri yönden ne derece bir değişim yaşadığını göstermesi açısından oldukça önemlidir. Yukarıdaki tablolarda silah antlaşmalarının içeriğine dair bilgiler verilmiştir. Antlaşmaların toplam maliyetlerine dair bilgiler ise aşağıdaki tabloda yer almaktadır.

1950-2009 arası ABD’nin Mısır ile yaptığı silah antlaşmaları maliyeti

\begin{tabular}{|c|c|c|c|c|c|}
\hline & $\begin{array}{c}\mathbf{1 9 5 0 -} \\
\mathbf{1 9 6 9}\end{array}$ & $\begin{array}{c}\mathbf{1 9 7 0 -} \\
\mathbf{1 9 7 9}\end{array}$ & $\begin{array}{c}\mathbf{1 9 8 0 -} \\
\mathbf{1 9 8 9}\end{array}$ & $\begin{array}{c}\mathbf{1 9 9 0} \\
\mathbf{1 9 9 9}\end{array}$ & $\begin{array}{c}\mathbf{2 0 0 0 -} \\
\mathbf{2 0 0 9}\end{array}$ \\
\hline $\begin{array}{c}\text { Silah } \\
\text { Antlaşmaları }\end{array}$ & 0 & $\begin{array}{c}632 \\
\text { milyon \$ }\end{array}$ & $\begin{array}{c}9.9 \\
\text { milyar \$ }\end{array}$ & $\begin{array}{c}10.5 \\
\text { milyar \$ }\end{array}$ & $\begin{array}{c}12.9 \\
\text { milyar \$ }\end{array}$ \\
\hline $\begin{array}{c}\text { Silah } \\
\text { Teslimatı }\end{array}$ & 0 & $\begin{array}{c}253 \\
\text { milyon \$ }\end{array}$ & $\begin{array}{c}4.6 \\
\text { milyar \$ }\end{array}$ & $\begin{array}{c}10 \text { milyar } \\
\text { \$ }\end{array}$ & $\begin{array}{c}12.3 \\
\text { milyar \$ }\end{array}$ \\
\hline
\end{tabular}

Kaynak: Clayton Thomas, Arms Sales in the Middle East: Trends and Analytical Perspectives for U.S Policy, Congressional Research Service Report, 11 Ekim 2017, https://fas.org/ sgp/crs/mideast/R44984.pdf, 30.

Körfez Krizi döneminde ABD-Mısır ortak tatbikatları iptal edilse de, kriz sonrasında ortak tatbikatlar yeniden başlatılmıştır. 1990'lı yıllardaki Bright Star tatbikatları sırasıyla 1996, 1998, 1999-2000 yıllarında gerçekleştirilmiştir. 1996 yılında ilk defa Mısır ve ABD dışında başka ülkeler de tatbikata dâhil edilmiştir. Fransa, Birleşik Krallık, Almanya, Birleşik Arap Emirlikleri ortak tatbikatta yer almıştır. Daha sonraki tatbikatlarda da kat1lan ülkelerin sayısı giderek artmış, 1999-2000 Bright Star tatbikatı 11 ülkenin katılımıyla 70.000'den fazla askeri birlik tarafından gerçekleştirilerek dikkatleri üzerine çekmiştir. Bu tatbikat sırasında birçok ülke de gözlemci olarak katılım göstermiştir. ${ }^{60}$ Ardından gerçekleşen 2001 tatbikatına ABD

59 Europa Publications, The Middle East and North Africa 1997, 394.

60 Jonathan Montgomery, "Operation Bright Star: A History of Multinational Forces Cooperation," 20 Eylül 2005, https://www.dvidshub.net/news/3070/operation-brightstar-history-multinational-forces-cooperation. 
ordusu yaklaşık 23.000 kişilik askeri birlik göndermiştir. 2002 y1lı sonrası Irak İşgali ile birlikte başlayan süreçte birkaç yıl iptal edilen tatbikat, 2005 yılında yeniden başlatılmıştır. Ardından 2007 ve 2009 yılında iki kez daha yapılmıştır. 2011 ve 2013 yılları arasında Mısır siyasetinde yaşanan gelişmeler tatbikatın aksamasına neden olmuştur. ${ }^{61} \mathrm{Bu}$ yıllarda yaşanan devrim ve darbe süreçleri sonrası tatbikat kaldığı yerden devam etmiştir. 8 y1l sonra Bright Star tatbikat 2017 yılında gerçekleştirilmiştir. ${ }^{62}$

Mübarek döneminde Bright Star askeri tatbikatı dışında da yapılan başka ortak tatbikatlar bulunmaktadır. Iron Cobra tatbikatı bunlardan bir tanesidir. Özel kuvvetlerin operasyonları konusunda yapılan bu ortak tatbikat 1984 yılında başlamış ve 1998 yılına kadar her yıl icra edilmiştir. Bir diğer ortak tatbikat da Eagle Salute tatbikatıdır. İki ülke donanmasının Kızıldeniz'de ortaklaşa gerçekleştirdiği Eagle Salute ortak deniz tatbikatı 1991'den beri her yıl yapılmıştır. Bir başka ortak tatbikat ise hava kuvvetleri alanında olmuştur. 1997 yılında tek seferlik olmak üzere Eagle Arena adı verilen hava kuvvetleri ortak tatbikatı icra edilmiştir. Bütün bu ortak tatbikatlar içerisinde en kapsamlı ve etkili tatbikat, yukarıda bahsi geçen, 1980'lerde başlayan ve sonrasında da devam eden Bright Star'dır. Çünkü bu tatbikat ile hava, kara ve deniz kuvvetleri ortaklaşa çalışmalar yapmışlardır. Ayrıca maliyet açısından 12 milyon doları bulan maliyetiyle bu alanda en yüksek maliyetli eylem olduğu belirtilmektedir. ${ }^{63}$ Bütün bu tatbikatlar olası bir ihtiyaç anında $\mathrm{ABD}$ ordusunun birlikte hareket edebileceği Mısır ordusu ile var olan uyumunu arttırmak amacıyla yapılmaktadır. Günümüzde de yapılmaya devam etmektedir.

11 Eylül 2001 tarihinde ABD'de yaşanan terör saldırısı dünyada şok etkisi yaratmıştır. Mısır Devlet Başkanı Mübarek ABD'deki saldırıyı kınadığını açıklamış, Başkan Bush ve Amerikan halkının yanında olduklarını belirtmiştir. ${ }^{64}$ Terör saldırısından sonra ABD önce Afganistan'ı işgal etmiş, daha

61 Mahmoud Gamal, "Bright Star Exercise: Dimensions and Interpretations," Egyptian Institute for Political and Strategic Studies, 23 Ağustos 2017, https://en.eipss-eg.org/ bright-star-dimensions-interpretations/.

62 Khaled Mohamed, "Egypt-U.S. military exercise 'Bright Star' to resume," 6 Eylül 2017, https://www.egypttoday.com/Article/1/21416/Egypt-U-S-military-exercise-BrightStar-to-resume.

63 Vogelsang, "U.S.-Egypt Security Cooperation after Egypt's January 2011 Revolution," 33-35.

64 Samer Shehata, "Egypt After 9/11: Perceptions of the United States," Social Science Research Council, 26 Mart 2004, http://conconflicts.ssrc.org/archives/mideast/ shehata/. 
sonra Irak'a operasyon yapma kararı almıştır. 2003 yılında Irak'a karşı planlanan saldırı Mısır-ABD ilişkilerini tartışmaya açmıştır. Mısır bu savaşa karş1 olumsuz bir tutum alarak uyarılarda bulunmuştur. Ancak, savaş sürecinde Türkiye'nin olası Irak Harekâtı için Güneydoğu sınırlarını açmayı kabul etmemesi sonrası Mısır devreye girmiştir. Mısır ABD'ye hava sahasını açmış ve ABD ordusunun Basra Körfezi'ne geçişi konusunda Süveyş Kanalı güzergâhını kullanımına izin vermiştir. ${ }^{65}$ Ayrıca bu süreçte M1sır, ABD ile istihbarat paylaşımı da gerçekleştirmiştir. Mübarek defalarca ABD liderliğindeki koalisyona destek vermediklerini, askeri çözümü reddettiklerini ve sorunun BM tarafından çözülmesi gerektiğini açıklamıştır. ${ }^{66}$ Buna rağmen Mısır'ın ABD ile iş birliğini sürdürmesi ABD-Mısır ilişkilerinin askeri-güvenlik boyutunu anlamak açısından dikkat çekici olmuştur. Mısır yönetiminin bu dönemde Mısır kamuoyundaki Amerikan karşıtlığının yükselmesini dikkate alarak Irak Operasyonu'na itiraz ettiği söylenebilir. ${ }^{67}$ Söylem ve eylem arasındaki farklılık bu açıdan değerlendirilmelidir.

ABD-Mısır iş birliğinin güvenlik alanındaki bir diğer boyutu istihbarattır. SSIS (State Security Investigation Service) adlı Misır istihbarat birimi CIA ile ortak çalışmalar yapmaktadır. Bu çalışmalar istihbarat değişimi ve eğitimini de içermektedir. 1998 yılına kadar süren bir program kapsamında CIA Mısır Özel Kuvvetleri’ne terörizme karşı mücadele etmesi amacıyla eğitim vermiştir. Diğer yandan, istihbarat söz konusu olduğunda Mübarek döneminde göreve başlayan ve 2011 devrimine kadar görevini sürdüren Ömer Süleyman'dan da bahsetmek gerekmektedir. CIA ile yakın ilişkileri olan Ömer Süleyman liderliğinde birçok ortak istihbarat çalışması gerçekleştirilmiştir. ${ }^{68}$

65 Trudy Kuehner, "The U.S. and Egypt Since the Suez Crisis," Foreign Policy Research Institute, 28 Temmuz 2009, https://www.fpri.org/article/2009/07/the-u-s-and-egyptsince-the-suez-crisis/.

66 Michele Black ve Osamah Alhenaki, "Business As Usual: The Egyptian-U.S. Intelligence Relationship," Global Security and Intelligence Studies, Cilt 1, No 1, (Sonbahar 2015): 2122, https://igitalcommons.apus.edu/cgi/viewcontent.cgi?article=1003\&context=gsis.

67 Samer Shehata'nın bu çalışmada da faydalandığımız makalesi dönemin Mısır kamuoyundaki Amerikan karşıtlığını anlamak açısından önemlidir. Bakınız: $\mathrm{Bu}$ çalışmadaki 66.dipnot.

68 Black ve Alhenaki, Business As Usual: The Egyptian-U.S. Intelligence Relationship, 22. 
Sonuç olarak Sedat döneminde başlayan askeri-güvenlik alanında ABDMısır işbirliği Mübarek döneminde artarak devam etmiştir. 30 yıl süren Mübarek iktidarında Mısır ordusu ABD'den çok sayıda silah ve mali yardım temin etmiştir. Mısırlı subaylar ABD'deki askeri merkezlerde eğitim alma imkanına sahip olmuşlardır. Mısır ve ABD ordusu çok sayıda ortak tatbikat gerçekleştirmiştir. ABD Mısır ordusuna vermiş olduğu desteğin karşılığını almış, Mısır ordusu ABD'nin bölgesel politikalarında kendisine katk1 sağlamıştır. Mübarek döneminde iki ülke askeri-güvenlik ilişkilerinin genel itibariyle çok olumlu bir seyir izlediği ifade edilebilir.

\section{2011 Devrimi Sonrası: SKYK ve Mursi Dönemi}

2010 yılının sonunda Tunus'ta başlayan Arap Devrimleri süreci 2011 y1l1na gelindiğinde Mısır'da da etkisini hissettirmiştir. Mısır halkının sokaklara dökülmesi ile birlikte Mübarek'in iktidardan çekilmesine kadar devam edecek olan 2011 Mısır Devrimi süreci başlamıştır. Bu süreçte ABD'nin Mısır'a yönelik yaklaşımı oldukça önemlidir. ABD hükümeti protestolar başladıktan üç gün sonra Mısır'a yönelik yaptığı dış yardımları yeniden değerlendireceğini açıklamıştır. Ancak birkaç gün sonra ABD Dış İşleri Bakanı Hillary Clinton dış yardımların kesilmesi konusunda herhangi bir tartışmanın olmadığını duyurmuştur. ABD hükümeti bu süreçte düzenli ve barışç1 bir geçiş süreci talep etmiş, ancak dış yardımlar konusunda herhangi bir yaptırım kararı almamıştır. ${ }^{69}$

Misır'da protestoların başarıya ulaşmasında ordunun tutumu belirleyici olmuştur. Başlangıçta tarafsız bir tutum sergileyen ordu, daha sonrasında ise harekete geçmiş ve yayınladığı bildiriler ile Mübarek'in istifasına giden süreci hızlandırmıştır. 11 Şubat 2011'de Hüsnü Mübarek'in istifası sonrası yeni dönemde Misır ordusu siyaset sahnesinde ön plana çıkarak Silahlı Kuvvetler Yüksek Konseyi (SKYK) aracığıyla geçiş sürecini yönetmeye başlamıştır. SKYK 6 aylık bir geçiş süreci için olmak kaydıyla siyasi liderliği eline aldığını ve daha sonra bunu demokratik yollarla seçilmiş hükümete devredeceğini duyurmuştur. SKYK'nın tasarrufuyla Yasama ve Şura meclisleri feshedilmiş ve Anayasa askıya alınmıştır. Cumhurbaşkanlığı yetkilerini SKYK Başkanı General Tantavi'nin yürütmesine, kanun yapma

69 Jeremy M. Sharp, "Egypt: January 25 Revolution and Implications for U.S Foreign Policy," 11-12. 
konusunda ise SKYK'nın yetkili olmasına karar verilmiştir. 6 ay süreyle verilen siyasi liderliğe ilişkin bu geçici yetkiler tam 17 ay sonra yeni hükümete devredilmiştir. Ordunun bu süreçte başat bir aktör olarak öne çıkması Mısır devlet yapısı içerisindeki kritik rolünü göstermiş ve devrim sonrası süreçte etkinliğini sürdüreceğinin işaretini vermiştir. ${ }^{70}$

Devrim sonrası Mısır ordusunun devlet yapısı içerisindeki konumunu ve sivil-asker ilişkilerinin yapısını daha iyi anlamak adına 2012 Anayasasına değinmek gerekmektedir. Mısır vatandaşları tarafindan onaylanan 2012 Anayasası içerisinde asker-sivil ilişkileri dengeli bir biçimde düzenlenmemiştir. Yeni anayasaya göre Savunma Bakanı'nın ordu mensubu bir isim olacağı belirtilmiştir. Ayrıca Ulusal Savunma Konseyi'nde askerlerin say1s1 sivillerden daha fazla olacak şekilde düzenlenmiştir. Böylece Mısır'ın savunma ve dış politika ile ilgili karar alma süreçlerinde ordunun veto yetkisine sahip olmasına imkân verilmiştir. Diğer yandan bir başka madde ile sivillerin Askeri Mahkemeler dâhilinde yargılanmasının önü açılmıştır. ${ }^{71}$ Bütün bunlar devrim öncesi ile sonrası dönemde ordunun rejim içerisindeki konumunu anlamak açısından önemlidir. Her ne kadar 2011 Devrimi sonrası seçimler gerçekleştirilse ve görünürde demokratik bir düzene geçilse de ordu sistem içerisindeki ağırlığını sürdürmüştür.

Geçiş sürecinde ABD-Mısır ilişkilerine bakıldığında ilk aşamada ABD'nin destek verici bir tutumunun olduğu söylenebilir. ABD bu dönemde yıllardır yapmış olduğu dış yardımlara ek olarak geçiş sürecinde yeni bir yardım paketi daha açıklamıştır. 165 milyon dolar değerindeki bu ekonomik yardım paketine ek olarak 1 milyar dolar değerinde ABD destekli kredi imkânı da sağlanmıştır. ${ }^{72}$ Öte yandan devrim sonrası karışık atmosferde uzun yıllardır gerçekleştirilen Bright Star Ortak Askeri Tatbikatı iptal edilmiştir. $^{73}$

70 Bekaroğlu ve Kurt, "Misır," 26-27.

71 Omar Ashour, "Ballots versus Bullets: The Crisis of Civil-Military Relations in Egypt," Brookings Institution, 3 Eylül 2013, https://www.brookings.edu/articles/ballots-versusbullets-the-crisis-of-civil-military-relations-in-egypt/.

72 Jeremy M. Sharp, "Egypt: Background and U.S. Relations," CRS Report for Congress, 26 Şubat 2013, http://www.au.af.mil/au/awc/awcgate/crs/rl33003.pdf, 12.

73 Marva Awad ve Phil Steward, "US, Egypt cancel largest Mideast military drill due to 'political situation,"” Al Arabiya News, 17 Ağustos 2011, http://www.alarabiya.net/ articles/2011/08/17/162800.html. 
Geçiş sürecinde Mısır-ABD ilişkilerini etkileyen kritik olay "STK Krizi" olmuştur. 2011 yılının sonunda yasadışı yollardan finanse edildikleri iddiasıyla Mısır'daki bazı Sivil Toplum Kuruluşları'na soruşturma açılmıştır. İçerisinde ABD vatandaşlarının da bulunduğu bu kurumların bazı çal1şanlarına yurtdışına çıkma yasağı getirilmiştir. Bu durum karşısında ABD Büyükelçiliği'ne sığınanlar da olmuştur. Kriz 2012 yılı başlarında da devam etmiş̧ir. ABD hükümeti bu süreçte her yıl Mısır'a yapılan dış yardımları kesebileceği uyarısında bulunmuştur. ${ }^{74}$ Mart 2012'ye kadar kriz devam etmiş, bu tarihte mahkemenin tutukluların seyahat yasaklarını kaldırması ve yapılan tutuklu takası ile birlikte son bulmuştur. ${ }^{75}$ Birkaç gün sonra da ABD hükümeti her yıl yapılan askeri yardımların devamı hususunda gerekli onaylamaları yapmışıır. ${ }^{76}$ STK krizi ABD-Mısır ilişkilerinin askeri boyutunun önemini ortaya koyan örneklerden bir tanesidir. ABD'nin krizi aşabilmek adına askeri yardımları bir tehdit unsuru olarak kullandığı ve ilk aşamada başarılı olduğu ifade edilebilir. Sisi döneminde STK Krizi bir kez daha gündeme gelecektir.

\section{Devrim-Darbe Arası Dönem (2011-2013) ABD'den Mısır'a Silah Transferleri}

\begin{tabular}{|c|c|c|c|c|}
\hline Silah Türü & Silah Modeli & $\begin{array}{c}\text { Sipariş } \\
\text { Yılı }\end{array}$ & $\begin{array}{c}\text { Sipariş } \\
\text { Adet }\end{array}$ & $\begin{array}{c}\text { Teslimat } \\
\text { Yılı }\end{array}$ \\
\hline $\begin{array}{c}\text { Elektro-Optik Hava } \\
\text { Sistemi }\end{array}$ & AAQ-33 Sniper & 2011 & 12 & $\begin{array}{c}2013- \\
2015\end{array}$ \\
\hline SIGINT Hava Aracı & Beech-1900 SIGINT & 2011 & 2 & 2012 \\
\hline Tank & M-1A1 Abrams & 2011 & 50 & $\begin{array}{c}2015- \\
2016\end{array}$ \\
\hline Devriye Gemisi & Swiftships-93 & 2011 & 4 & 2014 \\
\hline ARV & M-88 & 2013 & 13 & 2015 \\
\hline
\end{tabular}

Kaynak: Stockholm International Peace Research Institute (SIPRI) Arms Transfer Databese, http://armstrade.sipri.org/armstrade/page/trade_register.php.

74 “Mısır'dan STK'lara Suçlama,” Al Jazeera Türk, 8 Şubat 2012, http://www.aljazeera. com.tr/haber/misirdan-stklara-suclama.

75 Detaylar için bkz: “Mısır'da ABD’li STK'cılara şartlı af,” Dünya Bülteni, 1 Mart 2012, http://www.dunyabulteni.net/haber/199743/misirda-abdli-stkcilara-sartli-af.

76 "US to resume military aid to Egypt," Al Jazeera English, 23 Mart 2012, http://www. aljazeera.com/news/middleeast/2012/03/20123231597719505.html. 
Haziran 2012'de Cumhurbaşkanlığ seçimlerinin tamamlanmasıyla Mısır'da ilk sivil Cumhurbaşkanı Muhammed Mursi iş başına gelmiştir. Mursi döneminde Mısır-ABD ilişkileri ilk aylarda dengeli bir seyir izlemiş ancak daha sonra giderek olumsuz bir yöne doğru kaymıştır. Temmuz 2012'de Mısır'ı ziyaret eden ABD Dış İşleri Bakanı Hillary Clinton Mısır'daki geçiş sürecine desteklerini iletmiştir. Ayrıca bu süreçte Mısır'a mali yardım taahhüt etmiştir. Bununla birlikte Clinton Mısır'ın İsrail ile barışına da değinmiş, bunun bölgedeki istikrar adına önemli olduğunu vurgulamıştır. ${ }^{77}$ Eylül ayına gelindiğinde "Film Krizi" ortaya çıkmıştır. Bu dönemde Hz. Muhammed hakkında yayınlanan hakaret içerikli film birçok ülkede ABD'ye yönelik protestolara sebep olmuştur. Misır'da da bu protestolar gerçekleşmiş ve ABD Elçiliği'ne saldırı düzenlemiştir. Yaşanan bu olay ABD hükümetinin tepkisine yol açmıştır. ABD Başkanı Obama yapmış olduğu açıklamada Mısır'ın ABD'nin müttefiki olmadığını ancak düşmanı da olmadığını ifade etmiştir. Bunun yanında ABD hükümetinin hem bu kriz ile ilgili hem de İsrail ile barışın sürdürülmesi ile ilgili Mısır hükümetinin yaklaşımını yakından takip ettiğini vurgulamıştır. ${ }^{78}$ ABD'nin 1979' dan itibaren yakınlık kurduğu ve 1988'de NATO-Dış1 Müttefik statüsünü verdiği bir ülkeye yönelik bu tavrı dikkat çekici olmuştur. ABD'nin bu söylemleri yeni hükümete şüphe ile yaklaştığı şeklinde değerlendirilebilir.

Mursi döneminde Mısır-ABD arasında bazı sorunlar yaşansa da bu durum iki ülkenin askeri boyuttaki ilişkilerini kritik bir düzeyde etkilememiştir. ABD'nin her yıl Mısır'a yapmış olduğu 1,5 milyar dolar düzeyindeki askeri-mali yardımlar devam etmiş, silah antlaşmalarına yönelik ciddi bir yaptırım kararı alınmamıştır. Ancak, yukarıdaki tabloya bakıldığında anlaşılabileceği gibi, Mısır-ABD arasında silah antlaşmaları açısından geçmiş dönemlere göre bir azalma söz konusu olmuştur. Nitekim 2012 yılında Mısır'ın ABD'den herhangi bir silah siparişinde bulunmaması dikkat çekicidir.

77 “Clinton supports 'full transition'in Egypt," Al Jazeera English, 15 Temmuz 2012, http://www.aljazeera.com/news/middleeast/2012/07/20127148304248811.html.

78 'Mohammed film protests: Egypt 'neither an ally nor an enemy,' says Barack Obama”, The Telegraph, 14 Eylül 2012, http://www.telegraph.co.uk/news/worldnews/ barackobama/9542703/Mohammed-film-protests-Egypt-neither-an-ally-nor-anenemy-says-Barack-Obama.html. 


\section{Sisi Dönemi}

3 Temmuz 2013'te Misır Genelkurmay Başkanı Sisi önderliğinde gerçekleştirilen askeri darbe ile Mısır'da eski rejim yeniden inşa edilmiştir. ABD'nin darbeye yönelik ilk yaklaşımı darbenin "darbe" olarak nitelendirilmemesi olmuştur. ABD'nin bu kavramı kullanmamasının altında yatan temel sebep Mısır ile kurmuş olduğu askeri boyuttaki yakın ilişkilerdir. $\mathrm{ABD}$ yasalarına göre $\mathrm{ABD}$ hükümeti yaşanan bu olayları resmi olarak "darbe" şeklinde tanımladığı zaman bu askeri-mali yardımların çoğunu kesmesi gerekecekti. Böyle bir karar aldığında Mısır ordusuna zarar vermiş olacak ve devamında da Mısır-ABD ilişkilerinin bozulması gündeme gelecekti. ${ }^{79}$ Sonuç olarak, ABD meseleye çıkarları çerçevesinde yaklaşarak Sisi Darbesi'ni “darbe” olarak tanımlamamayı tercih etmiştir.

Darbe sonrası Misır ordusunun uygulamış olduğu şiddet ve yapılan katliamlar kamuoyunda büyük bir tepkiye sebep olmuştur. ABD hükümeti de bir adım atmak zorunda kalmış, Mısır'a yaklaşık 40 yıldır yapmış olduğu askeri yardımları askıya almıştır. Ayrıca diplomatik düzeyde bir adım daha atarak Kahire Büyükelçisi'ni ülkesine geri çağırmıştır. Ancak ABD’nin bu tavrı kısa süreli olmuş, 2013 yılı sonunda iki ülke gerginliği azaltmak adına yeniden temas kurmaya başlamıştır. 2014 yılının başlarında askeri yardımlar gündeme gelmiş, Obama hükümeti yardımların bir kısmının serbest bırakılmasını istese de ABD Kongresi'nden gelen baskılardan dolayı geri adım atmak zorunda kalmıştır. ${ }^{80}$

79 Thomson Reuters, "Why the U.S. doesn't call Egypt military's ouster of Morsi a coup," 4 Temmuz 2013, http://www.cbc.ca/news/world/why-the-u-s-doesn-t-call-egypt-militarys-ouster-of-morsi-a-coup-1.1347857.

80 Nebahat Tanrıverdi, “Kerry'nin Misır Ziyareti,” 29 Haziran 2014, http://orsam.org.tr/ orsam/DPAnaliz/13810?dil=tr. 
Sisi Dönemi (2013-2016) ABD’den Mısır'a Silah Transferleri

\begin{tabular}{|c|c|c|c|c|}
\hline Silah Türü & Silah Modeli & $\begin{array}{c}\text { Sipariş } \\
\text { Yulı }\end{array}$ & $\begin{array}{c}\text { Sipariş } \\
\text { Adet }\end{array}$ & $\begin{array}{c}\text { Teslimat } \\
\text { Yll }\end{array}$ \\
\hline SAM & $\begin{array}{c}\text { MIM-72C } \\
\text { Chaparral }\end{array}$ & 2014 & 200 & 2014 \\
\hline Anti-Tank Füze & AGM-114K Hellfire & 2015 & 178 & 2016 \\
\hline APC & Caiman & 2015 & 400 & 2016 \\
\hline Gaz Tribünü & LM-2500 & 2015 & 1 & 2015 \\
\hline APC & Maxxpro & 2015 & 12 & 2016 \\
\hline APC & RG-33 & 2015 & 350 & 2016 \\
\hline Nakliye Hava & C-130J Hercules & 2016 & 2 & - \\
\hline Aracı & $\begin{array}{c}\text { RGM-84L } \\
\text { Harpoon-2 }\end{array}$ & 2016 & 20 & - \\
\hline Anti-Gemi & Swiftships-93 & 2016 & 6 & - \\
\hline Devriye Gemisi & & & &
\end{tabular}

Kaynak: Stockholm International Peace Research Institute (SIPRI) Arms Transfer Databe-se, http://armstrade.sipri.org/armstrade/page/trade_register.php.

Bu dönemde dikkat çekici olan Sisi yönetiminin imzaladığı yeni silah antlaşmalarıdır. 2014 yılının Eylül ayında Rusya ile Hava Savunma Füze Sistemlerini de içeren 3,5 milyar dolar düzeyinde bir silah antlaşması yapılmıştır. ${ }^{81} 2015$ yılının Şubat ayında ise Fransa ile Mısır arasında toplamda 5,2 milyar avro düzeyinde bir başka silah antlaşması imzalanmıştır. $\mathrm{Bu}$ antlaşma çerçevesinde 24 adet Rafale Muharebe Jeti, çok amaçlı bir deniz firkateyni ve çok sayıda havadan-havaya füze teslimatının yapılacağı açıklanmıştır. ${ }^{82} \mathrm{Bu}$ antlaşmaların ABD ile ilişkilerin gerginleştiği bir dönemde gerçekleştirildiği düşünüldüğünde, Mısır'ın silah ticaretinde farklı ülkelere yönelerek ABD tekelini kırmak istediği söylenebilir. Mısır'ın son yıllardaki silah antlaşmalarıyla ilgili olan aşağıdaki tabloya bakıldığında son dönemde gerçekleşen politika değişikliği belirgin bir şekilde görülmektedir. Ancak Camp David sonrası gelişen ABD-Mısır askeri ilişkilerinin 30 yılı aşan bir birikime sahip olduğu unutulmamalıdır. Dolayısıyla bu antlaşmalara bakarak Mısır'ın askeri boyuttaki gereksinimleri yönünden

81 “Rusya Misır'a silah satıyor,” Al Jazeera Türk, 18 Eylül 2014, http://www.aljazeera. com.tr/haber/rusya-misira-silah-satiyor.

82 "Egypt signs 5.2 bln-euro deal for French jets, ships and missiles," Reuters, 16 Şubat 2015, https://www.reuters.com/article/egypt-france-arms/egypt-signs-5-2-bln-euro-deal-forfrench-jets-ships-and-missiles-idUSL5N0VQ3Q420150216. 
ABD'den tamamen vazgeçtiğini söylemek doğru değildir. Sisi yönetimindeki Mısır'ın farklı ülkelerle silah antlaşmaları yaparak kısa zamanlı askeri ihtiyaçlarını gidermeye çalıştığ ifade edilebilir. Ancak temel sebep bunun da ötesinde Mısır'ın ABD ile ilişkilerini yeniden Mübarek dönemindeki seviyeye çekmektir. Bu amaçla Mısır yönetimi ABD'nin bu politikalarının Mısır'1 ABD'den uzaklaştırarak Rusya, Fransa ve diğer güçlü aktörlere yaklaştıracağını göstermek istemiştir. Başka bir ifadeyle, ABD'nin uzun vadede Misır'1 kaybedebileceğini göstermek ve bu sayede ABD ile yeniden yakınlaşmak amacıyla silah antlaşmalarını bir araç olarak kullanmıştır. ABD-Mısır ilişkilerinin askeri boyutunun siyasal alanda da daima yans1maları olmaktadır.

\section{8-2015 arası Mısır'ın diğer ülkelerle silah transfer antlaşmaları maliyeti}

\begin{tabular}{|c|c|c|c|c|c|}
\hline Yll & ABD & Rusya & Çin & Avrupa Ülkeleri & Diğer \\
\hline $2008-2011$ & $\begin{array}{c}6.8 \\
\text { milyar \$ }\end{array}$ & $\begin{array}{c}500 \\
\text { milyon \$ }\end{array}$ & $\begin{array}{c}800 \\
\text { milyon \$ }\end{array}$ & $500 \quad \begin{array}{c}\text { milyon } \\
\text { \$ }\end{array}$ & 0 \\
\hline $2012-2015$ & $\begin{array}{c}1.3 \\
\text { milyar \$ }\end{array}$ & $\begin{array}{c}9.3 \\
\text { milyar \$ }\end{array}$ & $\begin{array}{c}400 \\
\text { milyon \$ }\end{array}$ & $\begin{array}{c}10.1 \\
\text { milyar \$ }\end{array}$ & $\begin{array}{c}400 \\
\text { milyon \$ }\end{array}$ \\
\hline
\end{tabular}

Kaynak: Catherine A. Theohary, Conventional Arms Transfers to Developing Nations 2008-2015, Congressional Research Service Report, 19 Aralik 2016, https://fas.org/sgp/ crs/weapons/R44716.pdf, 36.

Nitekim Mısır'ın bu politikası başarılı olmuştur. 2015 yılı Nisan ayında ABD hükümeti askıya almış olduğu askeri yardımları serbest bırakma kararı almıştır. Askıya alınan 12 adet F16 Uçağı, 20 adet Harpoon Füzeleri, 125 adet M1A1 Tank teslimatının yapılacağ 1 ve her yıl yapılan 1,3 milyar dolarlık askeri yardımların da devam edeceği Mısır yönetimine bildirilmiştir. ${ }^{83}$ Böylece iki ülke arasındaki gerginlik sona ermiştir.

2016 yılı sonunda göreve gelen Trump döneminde de Misır-ABD arasında genel itibariyle sıcak ilişkiler olduğu söylenebilir. Trump göreve geldikten hemen sonra Sisi kendisine tebriklerini iletmiş ve bunun karşılığında

83 Spencer Ackerman, "Obama restores US military aid to Egypt over Islamic State concerns," 31 Mart 2015, https://www.theguardian.com/us-news/2015/mar/31/obamarestores-us-military-aid-to-egypt. 
Başkan Trump iki ülke arasındaki güçlü ilişkileri vurgulayarak kendisini ABD'ye davet etmiştir. ${ }^{84}$ Nisan 2017'de beklenen ziyaret gerçekleştirilmiş Mısır Devlet Başkanı Sisi ABD'de Başkan Trump ile görüşmüştür. Burada Trump askeri iş birliğinin güçlendirilmesi gerektiğini söylemiştir. Bunun yanında, altı gün süren ziyaret sırasında Pentagon'a da uğrayan Mısırlı yetkilileri ABD Savunma Bakanı karşılamış ve burada iki ülke arasındaki askeri iş birliğinin geliştirilmesi vurgusu yapılmıştır. ${ }^{85}$

2017 yılının Ağustos ayında ABD-Mısır arasında ilişkileri zedeleyecek bir konu gündeme gelmiştir. Yukarıda da bahsi geçen STK Krizi’nde yeni bir sayfa açılmıştır. Bu dönemde Mısır'da yürürlüğe koyulan yeni yasa ile birlikte STK'lara yönelik kısıtlayıcı birtakım düzenlemeler yapılmıştır. "Ulusal güvenlik, kamu düzeni" ve benzeri gerekçelerle STK'lar üzerinde devlet kontrolü sağlayan bu düzenlemeye ABD tepki göstermiştir. Daha önceden yapmış olduğu dış yardımları kesme uyarısı doğrultusunda bir karar almıştır. Trump yönetimi tarafından yapılacak yardımın 291 milyon dolarlık kısmı dondurulmuştur. ${ }^{86} \mathrm{ABD}$ yönetiminin bu kararının arkasında STK Krizi'nden doğan rahatsızlığın yanında Kuzey Kore ile Mısır arasındaki yakın ilişkiler de yatmaktadır. 1970'lerden itibaren Kuzey Kore ile teması olan Mısır'ın bugün sivil ve askeri yönden bu ülke ile ilişki geliştirdiği belirtilmektedir. Örneğin; Mısır'ın en zengin iş adamlarından Necib Saviris'in sahip olduğu Telekomünikasyon şirketinin Kuzey Kore'de bu sektörün kurulması adına çalışmalar yaptığı ifade edilmektedir. ${ }^{87}$ Ayrıca iki ülke arasında uzun yıllardan beri askeri yönden ilişkiler geliştirildiği de belirtilmektedir. ${ }^{88}$

84 “Trump’tan Sisi’ye Washington Daveti," Sputnik Türkiye, 24.01.2017, https:// tr.sputniknews.com/dogu_akdeniz/201701241026902687-abd-trump-misir-sisidavet/.

85 "Sisi returns home after 6-day official visit to Washington," Egypt Today, 7 Nisan 2017, https:/www.egypttoday.com/Article/1/3795/Sisi-returns-home-after-6-day-officialvisit-to-Washington.

86 "Mısır'dan maddi yardımın bir kısmını donduran ABD’ye tepki," BBC, 23 Ağustos 2017, https://www.bbc.com/turkce/haberler-dunya-41026671.

87 Gardiner Harris ve Declan Walsh, "U.S. Slaps Egypt on Human Rights Record and Ties to North Korea," New York Times, 22 Ağustos 2017, https://www.nytimes.com/2017/08/22/ us/politics/us-aid-egypt-human-rights-north-korea.html.

88 Bu konuda önemli bir çalışma için bakınız: Declan Walsh, "Need a North Korean Missile? Call the Cairo Embassy," 3 Mart 2018, https://www.nytimes.com/2018/03/03/ world/middleeast/egypt-north-korea-sanctions-arms-dealing.html. 
Eylül 2017'de yapılan açıklama ile 9 yıl boyunca gerçekleştirilmeyen Bright Star Ortak Askeri Tatbikatının yeniden başlatılacağı duyurulmuştur. Böylelikle iki ülke arasında askeri alanda yaşanan sorun aşılmıştır. ${ }^{89}$ ABD'nin Mısır'a yaptırımlarını sınırlı tutması ilişkilerini tamamen koparmadan yürütmek istediği şeklinde yorumlanabilir. STK Krizi iki ülke arasındaki ilişkilere zarar verse de iki ülke birçok alanda iş birliğini sürdürmüştür. Askeri boyuttaki ilişkiler bu dönemde de devam etmiştir.

Mısır-ABD ilişkilerinde askeri boyutun sıklıkla vurgulanması önemlidir. Bu çalışmada da belirtildiği üzere askeri ilişkiler iki ülke arasındaki ilişkilerin temelini oluşturmaktadır. Trump yönetimi de ilişkilerin bu boyutuna dikkatleri çekmiştir. Sonuç olarak, 2018 yılı itibariyle iki ülke arasındaki sıcak ilişkiler devam etmekte ve bazı sorunlar yaşansa da Başkan Trump döneminde Misır ile ilişkilerin olumlu bir biçimde sürmesi beklenmektedir. 2018'de yapılan göstermelik bir seçim sonucunda Sisi yeniden Mısır Devlet Başkanı olarak seçilmiştir. Ardından Başkan Trump kendisini tebrik etmiş, ABD'nin Mısır ile ortaklığına değer verdiğini ve iki ülkenin ortak hedefler doğrultusunda hareket edeceğini vurgulamıştır. ${ }^{90}$ Misır ABD'nin Ortadoğu'daki en önemli müttefiklerinden birisi olarak varlığını sürdürmekte, askeri boyuttaki ilişkiler de bu ittifakın temelini oluşturmaktadır.

\section{Sonuç}

Camp David Süreci ile birlikte Mısır ile ABD arasında bir yakınlaşma başlamıştır. Ekonomik, ticari, siyasi, diplomatik vb. birçok boyutu olan bu yakınlaşmanın en kritik boyutu askeri boyutudur. Bu çalışmada da iki ülke arasındaki yakınlığın askeri boyutu ele alınmıştır. ABD Mısır ile askeri alanda kurmuş olduğu ilişkiler yoluyla bölge politikalarında iş birliği içerisinde çalışabileceği bir ordu kazanmayı amaçlamaktadır. Mısır ordusu için ABD yardımları (silahlar, ortak tatbikatlar, eğitim vb.) oldukça kritiktir. Diğer yandan, Mısır ordusunun Mısır devlet yapısı içerisindeki etkili konumu düşünüldüğünde ABD'nin ordu ile kurmuş olduğu bu ilişkinin

89 "Egypt says suspended U.S. military exercises to resume," Reuters, 5 Eylül 2017, https://www.reuters.com/article/us-egypt-usa-military/egypt-says-suspended-u-smilitary-exercises-to-resume-idUSKCN1BG2I8.

90 “Donald Trump'tan Sisi'ye tebrik telefonu," Milliyet, 2 Nisan 2018, http://www.milliyet. com.tr/donald-trump-tan-sisi-ye-tebrik-dunya-2639744/. 
siyasette de olumlu yansımaları olduğu ifade edilebilir. 1980'lerde gelişen askeri yakınlaşma sonunda 1988 yılında Mısır'a Nato-dışı müttefik statüsü verilmesiyle önemli bir aşamaya geçilmiştir. 1990'lardaki Körfez Krizi sürecinde Misır ve ABD'nin ortak hareket etmesi, Irak Harekatı'nda Misır'ın ciddi katkısının olması askeri alandaki iş birliğinin pratikteki kayda değer örnekleri olmuşlardır. Öte yandan, iki ülkenin ordusu 1980'lerden itibaren belli aralıklarla ortak tatbikat çalışmaları gerçekleştirmişlerdir. Günümüzde de bu çalışmalar yapılmaya devam etmektedir. Bir diğer iş birliği alanı silah ve askeri araç satışıdır. Mısır ordusu 1980'li yıllardan itibaren ABD yapımı silah ve askeri araçları satın almayı tercih etmektedir. İki ülkenin askeri alandaki iş birliğinin kritik unsurlarından birisi de mali yardımlardır. Mısır ordusu ABD'den her yıl ortalama 1,5 milyar dolar düzeyinde mali yardım almaktadır. ABD'nin Mısır'a yönelik siyasetinde bir aktör olarak orduya değer vermesinin sebepleri Misır ordusunun Misır siyasetindeki konumunda aranmalıdır. Mısır'da ordu ekonomi dâhil birçok alanda en etkili aktör olarak öne çıkmakta, Mısır siyasetinin başat aktörü olarak görünmektedir. Bu durum ABD'nin Misır politikasında askeri boyuta kritik bir önem atfetmesine ve Misır ile askeri alanda iş birliklerini geliştirmesine zemin hazırlamıştır. Sonuç olarak; askeri alandaki bütün bu iş birliklerinin zaman içerisinde Mısır ordusunun ABD'yle bağını giderek arttırdığg ifade edilebilir. Bir başka ifadeyle, ABD'nin Mısır ordusu üzerindeki etkisi Camp David sonrası süreçte her geçen gün artmıştır. Bu etki sayesinde ABD Sedat ve Mübarek dönemlerinde Ortadoğu'daki bölgesel politikalarında Mısır ordusundan destek sağlamıştır. İran Rehine Operasyonu, Yeşil Kuşak Projesi, Körfez Operasyonu, Irak Harekatı bu konuda verilebilecek kayda değer örneklerdir. Bununla birlikte 2010 yılında Hüsnü Mübarek'e karşı halk ayaklanması ortaya çıktığında ordunun kendi pozisyonunu belirlemesinde ABD'nin belli ölçüde etkisinin olduğu söylenebilir. Aynı şekilde, 2013 y1lındaki Sisi Darbesi ile Mursi iktidarının devrilmesi sürecinde de ABD'nin tutumunun darbe ve sonrasında yaşanan gelişmelerde etkili olduğu ifade edilebilir Elbette, Misır ordusunun bütün bu kararlarında ABD'ye bağımlı hareket ettiğini ve ABD'nin sözünden çıkmadığını söylemek doğru bir yaklaşım olmayacaktır. Ancak, iş birliğinin bu kadar yoğun olduğu göz önünde bulundurulduğunda ve iki ülke arasındaki ilişkilerin askeri boyutunun tarihsel seyri incelendiğinde ABD'nin Misır ordusu üzerinde kayda değer bir etkisinin olduğu ileri sürülebilir. 


\section{Kaynakça}

Aly, Abdul Monem Said, "Egypt: A Decade After Camp David," The Middle East: Ten Years After Camp David, ed. William B.Quandt, 63-93. Washington: Brookings Institutions, 1988.

Ayubi, Nazih N., Over-Stating The Arab State: Politics and Society in the Middle East, Londra ve New York: I. B. Tauris Publishers, 1995.

Barnaby, Frank, "A Frangible Peace," The Bulletin Of The Atomic Scientists, Cilt 36, No 8, (Ekim 1980): 7-8. https://doi.org/10.1080/00963402.1 980.11458763, (Erişim Tarihi: 08.03.2018).

Bekaroğlu, Edip Asaf ve Veysel Kurt, "Mısır'da Otoriter Rejimin Sürekliliği ve Ordu: ‘Arap Baharı' ve Sonrası Sürecin Analizi,” Türkiye Ortadoğu Çalışmaları Dergisi, Cilt 2, Sayı 2, (2015): 1-36.

Bilgin, Abdul Rezak, Arap Baharı Sürecinde Orduların Tutumu: Mısır, Libya ve Tunus Örnekleri, Ankara: Birleşik Yayınları, 2014.

Cleveland, William L., Modern Ortadoğu Tarihi, İstanbul: Agora Kitaplığ1, 2008.

Cook, Steven A., Yönetmeden Hükmeden Ordular, İstanbul: Hayy Kitap, 2008.

Cook, Steven A., The Struggle for Egypt: From Nasser to Tahrir Square, New York: Oxford University Press, 2012.

Dessouki, Ali E. Hillal, "Egyptian Foreign Policy Since Camp David,” The Middle East: Ten Years After Camp David, ed. William B.Quandt, 94-110. Washington: Brookings Institutions, 1988.

Eilts, Hermann Frederick, "The United States and Egypt," The Middle East: Ten Years After Camp David, Ed. William B.Quandt, 111-149. Washington: Brookings Institutions, 1988.

Europa Publications, The Middle East and North Africa 1997, London: Europa Publications, 1997.

Hinnebusch Jr., Raymond A., Egyptian Politics Under Sadat, Cambridge: Cambridge University Press, 1985.

Karawan, Ibrahim A., "Egypt," The Political Role of the Military: An International Handbook, ed. Constantine P. Danopoulos ve Cynthia Watson, Westport: Greenwood Press, 1996. 
Mansfield, Peter, Ortadoğu Tarihi, İstanbul: Say Yayınları, 2012.

Marsot, A. Lutfi al-Sayyid, Misır Tarihi: Arapların Fethinden Bugüne, İstanbul: Tarih Vakfi Yurt Yayınları, 2010.

Morsy, Soheir A., "U.S Aid to Egypt: An Illustration and Account of U.S. Foreign Assistance Policy," Arap Studies Quarterly, Cilt 8, No 4, (Sonbahar 1986): 358-389.

Moussa, Mohammed, "Kışla, Ekonomi ve Siyaset Üçgeninde Mısır Ordusu," Ortadoğu'da Ordu ve Siyaset, ed. Veysel Kurt, 77-102. İstanbul: Seta Yayınları, 2017.

Owen, Roger, State, Power \& Politics in The Making of the Modern Middle East, Londra ve New York: Routledge, 1992.

Quandt, William B., The United States and Egypt: An Essay on Policy for 1990's, Washington: Brookings Institutions, 1990.

Şahin, Mehmet, “ABD’nin ‘Müslüman' Savaşçıları,” Akademik Ortadoğu, Cilt 3, Say1 1, (2008): 43-52.

\section{Internet Kaynakları}

Abul-Magd, Zeinab, "The Egyptian military in politics and the economy: Recent history and current transition status," CMI Insight, Ekim 2013, Say1 2, https://www.cmi.no/publications/file/4935-the-egyptian-militaryin-politics-and-the-economy.pdf, (Erişim Tarihi: 15.04.2018).

Ackerman, Spencer "Obama restores US military aid to Egypt over Islamic State concerns," 31 Mart 2015, https://www.theguardian.com/usnews/2015/mar/31/obama-restores-us-military-aid-to-egypt, (Erişim Tarihi: 19.02.2018).

Al Jazeera English, "Clinton supports 'full transition' in Egypt," 15 Temmuz 2012, http://www.aljazeera.com/news/middleeast/2012/07/201271483042 48811.html, (Erişim Tarihi: 19.02.2018).

A1 Jazeera English, "US to resume military aid to Egypt," 23 Mart 2012, http://www.aljazeera.com/news/middleeast/2012/03/20123231597719505. html, (Erişim Tarihi: 17.02.2018). 
Al Jazeera Türk, “Mısır'dan STK'lara Suçlama," 8 Şubat 2012, http://www. aljazeera.com.tr/haber/misirdan-stklara-suclama, (Erişim Tarihi: 17.02.2018).

Al Jazeera Türk, “Rusya Misır’a silah satıyor,” 18 Eylül 2014, http://www. aljazeera.com.tr/haber/rusya-misira-silah-satiyor, (Erişim Tarihi: 03.03.2018).

Ashour, Omar, "Ballots versus Bullets: The Crisis of Civil-Military Relations in Egypt," Brookings Institution, 3 Eylül 2013, https://www.brookings. edu/articles/ballots-versus-bullets-the-crisis-of-civil-military-relations-inegypt/, (Erişim Tarihi: 16.05.2018).

Awad, Marva ve Phil Steward, "US, Egypt cancel largest Mideast military drill due to political situation," Al Arabiya News, 17 Ağustos 2011, http://www.alarabiya.net/articles/2011/08/17/162800.html, (Erişim Tarihi: 17.02.2018).

BBC, "Misır'dan maddi yardımın bir kısmını donduran ABD'ye tepki," 23 Ağustos 2017, https://www.bbc.com/turkce/haberler-dunya-41026671, (Erişim Tarihi: 16.05.2018).

Black, Michele ve Osamah Alhenaki, "Business As Usual: The EgyptianU.S. Intelligence Relationship," Global Security and Intelligence Studies, Cilt 1, No 1, (Sonbahar 2015): 13-30. https://digitalcommons.apus.edu/cgi/ viewcontent.cgi?article $=1003 \&$ context $=$ gsis, (Erişim Tarihi: 08.03.2018).

Deen, Thalif, "Egyptian Army's Firepower Overwhelmingly U.S.Supplied," IPS Haber Ajans1, 9 Temmuz 2013, http://www.ipsnews.net/20 13/07/egyptian-armys-firepower-overwhelmingly-u-s-supplied/, (Erişim Tarihi: 04.02.2018).

Dünya Bülteni, “Mısır'da ABD'li STK'cılara şartlı af,” 1 Mart 2012, http://www.dunyabulteni.net/haber/199743/misirda-abdli-stkcilara-sartliaf, (Erişim Tarihi: 17.02.2018).

Egypt Today, "Sisi returns home after 6-day official visit to Washington," 7 Nisan 2017, https://www.egypttoday.com/Article/1/3795/Sisi-returnshome-after-6-day-official-visit-to-Washington, (Erişim Tarihi: 03.03.2018).

Gamal, Mahmoud, "Bright Star Exercise: Dimensions and Interpretations," Egyptian Institute for Political and Strategic Studies, 23 Ağustos 2017, https://en.eipss-eg.org/bright-star-dimensions-interpretations/, (Erişim Tarihi: 08.03.2018). 
Harris, Gardiner ve Declan Walsh, "U.S. Slaps Egypt on Human Rights Record and Ties to North Korea," New York Times, 22 Ağustos 2017, https://www.nytimes.com/2017/08/22/us/politics/us-aid-egypt-humanrights-north-korea.html, (Erişim Tarihi: 17.05.2018).

Kuehner, Trudy, "The U.S. and Egypt Since the Suez Crisis," Foreign Policy Research Institute, 28 Temmuz 2009, https://www.fpri.org/article/2009/07/ the-u-s-and-egypt-since-the-suez-crisis/,(Erişim Tarihi: 10.12.2017).

Milliyet, "Donald Trump'tan Sisi'ye tebrik telefonu," 2 Nisan 2018, http:// www.milliyet.com.tr/donald-trump-tan-sisi-ye-tebrik-dunya-2639744/, (Erişim Tarihi: 18.05.2018).

Mohamed, Khaled, "Egypt-U.S. military exercise 'Bright Star' to resume," 6 Eylül 2017, https://www.egypttoday.com/Article/1/21416/Egypt-U-Smilitary-exercise-Bright-Star-to-resume, (Erişim Tarihi: 08.12.2017).

Montgomery, Jonathan, "Operation Bright Star: A History of Multinational Forces Cooperation," 20 Eylül 2005, https://www.dvidshub.net/ news/3070/operation-bright-star-history-multinational-forces-cooperation, (Erişim Tarihi: 08.12.2017).

New York Times, "U.S. Accuses 2 Egyptian Colonels In Plot to Smuggle Missile Material," 25 Haziran 1988, http://www.nytimes.com/1988/06/25/ world/us-accuses-2-egyptian-colonels-in-plot-to-smuggle-missilematerial.html?pagewanted=all, (Erişim Tarihi: 08.12.2017).

Reuters, "Egypt says suspended U.S. military exercises to resume," 5 Eylül 2017, https://www.reuters.com/article/us-egypt-usa-military/egypt-sayssuspended-u-s-military-exercises-to-resume-idUSKCN1BG2I8, (Erişim Tarihi: 04.03.2018).

Reuters, "Egypt signs 5.2 bln-euro deal for French jets, ships and missiles," 16 Şubat 2015, https://www.reuters.com/article/egypt-france-arms/egypt-signs-5-2bln-euro-deal-for-french-jets-ships-and-missiles-idUSL5N0VQ3Q420150216, (Erişim Tarihi: 03.03.2018).

Reuters, Thomson "Why the U.S. doesn't call Egypt military's ouster of Morsi a coup," 4 Temmuz 2013, http://www.cbc.ca/news/world/why-theu-s-doesn-t-call-egypt-military-s-ouster-of-morsi-a-coup-1.1347857, (Erişim Tarihi: 19.02.2018). 
Sayigh, Yezid, "Above the State: The Officers Republic in Egypt," Carnegie Middle East Center, Ağustos 2012, http://carnegieendowment.org/ files/officers_republic1.pdf, (Erişim Tarihi: 14.04.2018).

Sharp, Jeremy M., "Egypt: Background and U.S. Relations," CRS Report for Congress, 26 Şubat 2013, http://www.au.af.mil/au/awc/awcgate/crs/ rl33003.pdf, (Erişim Tarihi: 08.03.2018).

Sharp, Jeremy M., "Egypt: January 25 Revolution and Implications for U.S Foreign Policy," CRS Report for Congress, 11 Şubat 2011, http:// www.refworld.org/pdfid/4d6f4dc5c.pdf, (Erişim Tarihi: 08.03.2018).

Sharp, Jeremy M., "Egypt-United States Relations," CRS Issue Brief for Congress, 15 Haziran 2005, http://www.au.af.mil/AU/AWC/AWCGATE/ crs/ib93087.pdf, 14, (Erişim Tarihi: 08.03.2018).

Shehata, Samer, "Egypt After 9/11: Perceptions of the United States," Social Science Research Council, 26 Mart 2004, http://conconflicts.ssrc.org/ archives/mideast/shehata/, (Erişim Tarihi: 10.12.2017).

Shibab-Eldin, Ahmed, "Egypt's American-Made Military: More Mistakes Than Morsi," Huffington Post, https://www.huffingtonpost.com/ahmedshihabeldin/egypts-americanmade-milit_b_3549340.html, (Erişim Tarihi: 08.12.2017).

Sputnik Türkiye, “Trump'tan Sisi'ye Washington Daveti," 24.01.2017, https://tr.sputniknews.com/dogu_akdeniz/201701241026902687-abdtrump-misir-sisi-davet/, (Erişim Tarihi: 03.03.2018).

Stockholm International Peace Research Institute (SIPRI) Arms Transfer Databese, http://armstrade.sipri.org/armstrade/page/trade_register.php, (Erişim Tarihi: 24.02.2018).

Tadros, Sherine, "Egypt military's economic empire," 16 Şubat 2012, Al Jazeera English, https://www.aljazeera.com/indepth/features/2012/02/20122 15195912519142.html, (Erişim Tarihi: 08.03.2018).

Tanriverdi, Nebahat "Kerry'nin Misır Ziyareti," 29 Haziran 2014, http:// orsam.org.tr/orsam/DPAnaliz/13810?dil=tr, (Erişim Tarihi: 19.02.2018).

Tavana, Daniel L., "U.S. Security Assistance to Egypt: Military Aid and Legislative Conditionality," Cenevre Silahlı Kuvvetler Demokratik Kontrol Merkezi-DCAF tarafindan düzenlenen konferansta sunulan çalışma, Montrö, 2-4 Nisan 2014, https://www.observatoire-securite.tn/wp-content/ 
uploads/sites/4/2016/11/Egypt-Civil-Military-Relations-ConferencePaper-Series.pdf, (Erişim Tarihi: 07.12.2017).

The Telegraph, "Mohammed film protests: Egypt "neither an ally nor an enemy', says Barack Obama," The 14 Eylül 2012, http://www.telegraph. co.uk/news/worldnews/barackobama/9542703/Mohammed-film-protestsEgypt-neither-an-ally-nor-an-enemy-says-Barack-Obama.html, (Erişim Tarihi: 19.02.2018).

Theohary, Catherine A., "Conventional Arms Transfers to Developing Nations 2008-2015," Congressional Research Service Report, 19 Aral1k 2016, https://fas.org/sgp/crs/weapons/R44716.pdf, (Erişim Tarihi: 11.03.2018).

Thomas, Clayton, Arms Sales in the Middle East: Trends and Analytical Perspectives for U.S Policy, Congressional Research Service Report, 11 Ekim 2017, https://fas.org/sgp/crs/mideast/R44984.pdf, (Erişim Tarihi: 11.03.2018).

Vogelsang, Susan S., "U.S.-Egypt Security Cooperation after Egypt's January 2011 Revolution," U.S. Department of State, 2011, http://www.dtic. mil/dtic/tr/fulltext/u2/a557655.pdf, (Erişim Tarihi: 07.12.2017).

Walsh, Declan, "Need a North Korean Missile? Call the Cairo Embassy," 3 Mart 2018, https:/www.nytimes.com/2018/03/03/world/middleeast/egyptnorth-korea-sanctions-arms-dealing.html, (Erişim Tarihi: 17.05.2018). 